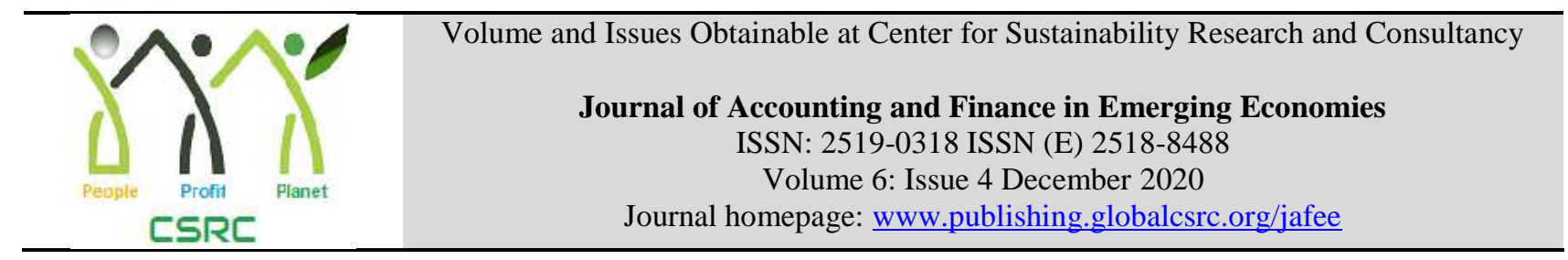

\title{
Revisiting the Dividend and Investment Puzzle: An International Review using US Corporate Governance Data
}

\author{
${ }^{1}$ Farhan Mahboob
}

${ }^{1}$ Senior Lecture Muhammad Ali Jinnah University, Karachi, Pakistan, farhan.mahboob@jinnah.edu

\begin{tabular}{l} 
ARTICLE DETAILS \\
\hline History \\
Revised format: November \\
2020 Available Online: \\
December \\
2020 \\
\hline Keywords \\
Dividend (imputation) policy, tax \\
(free), capital investment, board \\
of director remuneration, \\
corporate profitability, corporate \\
governance.
\end{tabular}

JEL Classification:

G35, G32, G34, C33

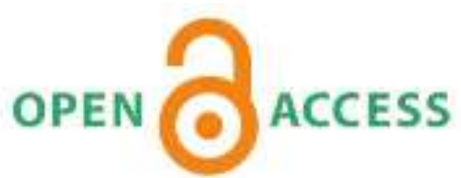

\section{ABSTRACT}

This explanatory comparative review uses pooled regression, weighted least squares and GLS panel analysis on 943 listed US firms (2005-2009), while examining the effect of corporate governance (good and questionable), profitability and sales revenue on dividends and investment, seeking to examine the different aspects of the dividend and investment puzzle. After rigorous robust scrutiny, the research empirically endorses the claim that Corporate governance pursue investment decision, while curbing dividend payout, profoundly by questionable corporate governance; cash dividends are seldom given in the US. Sales Revenue (and the firm's value) boost investments, while its positive influence on dividends is insignificant. All other tactics impede Dividend policy, most profoundly by the firm's value. Taxable income impedes investment. On the other hand, the firm's value and sales revenue do significantly influence corporate investment decisions, as postulated by the pecking order, capital structure substitution and residual theories. The empirical results reveal the latent capitalization/expensing ploy used by listed firms. Results suggest that US firms prefer investing funds generated from sales revenue, while expensing off tax deductible profits, thus benefiting from both the virtues of capital investment and expensing. Tax implication as well as the fallacy of dividend avoidance is also examined, apart from recommending policy for regulatory authorities as well as governors (board of directors) of firms to pursue.

(C) 2020 The authors, under a Creative Commons AttributionNonCommercial 4.0

Corresponding author's email address: farhan.mahboob@jinnah.edu

Recommended citation: Mahboob, F. (2020). Revisiting the dividend and investment puzzle: An international review using US corporate governance data. Journal of Accounting and Finance in Emerging Economies, 6(4), 967-994

\section{Introduction - The Evolution of Dividends}

"The harder we look at the dividend picture, the more it seems like a puzzle, with pieces that just don't fit together."

(Fischer Black, 1976, The Dividend Puzzle)

Since the dawn of the corporate era, dividend policy has been constantly evolving. The pioneer 
incorporated enterprises were free of the notion of dividends. The first American corporation (Frankfurter, Wood \& Wansley, 2003), The New London Society United for Trade and Commerce, was established in 1732; there is lack of evidence pointing towards a dividend policy. In 1776 (although originally founded in 1760), the Union Warf Company of New Haven, became the second company to be incorporated in the United States. The first cooperation with modern corporate features was chartered in 1768 - The Philadelphia Contribution for the Insuring of Houses from loss by fire. Earnings were used for expanding operation, as there were significant growth opportunities. It was not until the $18^{\text {th }}$ Century that we find evidence for dividends. Gradually cash dividends acquired the prime directive status of conservative investors. However, the emerging corporate trend is devoid of cash dividends (Skinner, 2008), strictly based on repurchases.

Lintners's (1956) pioneering work established an association between earning and dividend. The Miller-Modigliani dividend model (1961) stressed the irrelevance of dividends in a corporate world devoid of tax (Copeland \& Weston, 1992) and transactional costs, with flourishing information asymmetry. When corporate and individual taxes were introduced Farar and Selwyn (1967) argued in favor of anti-dividend policy, propagated as the best course of action (Brennan, 1970). Many researchers (like Shaffer, 2001) question the wisdom of dividends in light of the double taxation regulation. Perhaps, dividends finance investors preferred consumption streams under certain conditions. Or perhaps, because a specific kind of dividend smoothing facilitates dynamic portfolio insurance in the face of riskfree security alternatives. Or have minority shareholder rights and interests permeated regulatory bodies? Big US companies like Microsoft- as a policy did not pay dividends! Should it be required to by law?

\subsection{The Dividend Puzzle}

The theorems of Modigiliani-Miller (1959 \&1961) constitute the basic foundation of capital structure in finance; the market price of the firm is not influenced by the financial structure of the firm. This theorem of capital structure lead to the evolution of the dividend puzzle; investors overvalue firms that issue dividends, although firm valuation should remain the same where the firm's payout dividend or reinvests it. Fischer Black (1976) set out to put the different piece of the dividend puzzle together, but only succeeded in concluding that the different pieces do not fit together. The dividend puzzle stemming from the theorem is tantamount to saying that the financial decision of the firm does not affect its valuation. Miller and Scholes (1978) added a cautious note to the Miller-Modigliani (1961) theory, by suggesting that to a large extent, dividends would be sheltered from tax. Of course, it was not until 2003 that the Bush Administration lowered dividend taxes, while Australia and New Zealand, and in their own right, the British had already introduced dividend imputations.

\subsection{Dividend Policy}

History has witnessed different dividend policies; stable dividend-per-share policy, constant dividend payout ratio, a compromise policy, and the residual-dividend policy. Fama and Babiak (1968) investigated many different models for analyzing dividend behavior, using a sample of 201 companies, during the period 1947 to 1964 . Of the numerous models they tested, Lintner's model and a similar model that suppresses the constant term and adds a term for the lagged level of earnings, were the best. Fama and French (2001) have also noticed a significant drop in cash dividends, from 66.5\% in 1978 to $20.8 \%$ in 1999. Amongst other things the research notes that the listing of newer small firms, with growth opportunities many be one reason for this drop. Skinner (2008) identified three distinct categories of dividend payouts policy: (i) companies that pay dividends and also make regular repurchases, (ii) companies that make regular repurchases, (iii) companies that make occasional repurchases. A purely dividend pay-out policy only is extinct; the emerging trend is that of repurchases.

In the post-Lintner period, significant research has been conducted to establish a relationship (Simons, 1994) between operating cashflows, earning and dividend, however, without much success. In last decade, attention has shifted towards cashflow reporting. Charitou and Vafeas (1998) re-evaluated prior 
studies to empirically establish the notion that dividend changes-cashflow correlation is both significant as well as positive when cashflow are less in comparison to earnings, and when the corporation's growth is moderate.

\section{Literature Review}

Ferris, Jayaraman, and Sabherwal (2009) test an international sample of twenty-three countries, only to find that evidence of dividend catering is amongst those companies incorporated in common law countries, but not for those incorporated in civil law countries. The study found that dividend catering was evident in countries of common law, when legislation (with investor protection), in an environment in which investor demanded dividend (from the management) and placed a high value on dividend paying firms. Further, the study found that in countries of civil law, that the failure to cater dividends was evident in the consumption of private benefit of control or a lack of interest in responding to temporary market misevaluation of equity.

Braggion and Moore (2011) in a historical (1895 - 1905) analysis of 469 British firms, found strong support for asymmetric information/signaling theories of dividend policy, as they operated in the absence of institutional parameters and minimal taxes. The study also found little support for the agency problem. Howe and Lin (1992) empirically tested the inverse relationship between dividend yield and bid-ask spread. Mitton (2004) used a sample of 365 firms from 19 countries to establish a strong correlation between strong corporate governance and higher dividend payouts, in accordance with the agency models of dividends. The findings hold for countries with strong investor protection. DeAngelo, DeAngelo and Stultz (2006) tested and verified the life-cycle theory with respect to dividend policy. A highly significant relationship exists between decision to pay dividends and the earned/contributed capital mix, after controlling for variable like profitability, growth, size, total equity dividend history, etc. The study uses regressional analysis to demonstrate that the ratio of earned/contributed capital has an empirically greater effect than measures of profitability and growth. Christie and Nanda (1994) examined the effect of the unexpected tax imposed by the US federal government on undistributed corporate profits. Denis and Osobov (2008) examined the propensity to pay dividends in the US, Canada, France, Germany, and Japan. In general, the findings support agency cost-based lifecycle theories, while questioning signaling, clientele, and catering explanations of dividend. Goergen, Renneboog, and Correia da Silva (2004) compared dividend pay-out ratio of German firms (based on cash flow) to UK and USA firms. Liljeblom and Pasternack (2006) studied the variables that determine share repurchases and dividend in Finland.

\subsection{Taxation Policy on Dividend, Investment and Valuation}

Numerous studies have analyzed the effect of taxation policy (Halperin, 1983; Alli, Khan \& Ramirez, 1993; Collins \& Kemsley, 2000; Bond et al., 2003; Guenther \& Sansing, 2006; Grubert, 2009) on dividend, investment and valuation. Halperin (1983) examined how the perceived instability of taxation legislation affects consumption-investment decisions. Alli, Khan and Ramirez (1993) used factor analysis and multiple regression (a two-step procedure) to test alternative explanations of dividend policy. Over all the results supported the tax clientele theory. Grubert (2009) investigated the effect of residual home country tax policy on dividends from foreign subsidiaries, as well as tax holidays and the burden of the repatriation tax. The findings of the research were inconsistent with the Hartman-Sinn 'New View' as well as the Weichenreider and Altshuler-Grubert repatriation avoidance models. Sterk and Vandenberg (1990), as well as Long (1987) and Poterba's (1986) Citizen Utilities case, conclude that the taxation policy does in fact influence valuation. Boyce and Riddle (2008) gave two innovative viable alternatives (taxable dividends and tax-free dividends) to the US government carbon cap policy. Harris, Hubbard, Glenn and Kemsley (2000) analyzed the hypothesis that dividend taxes are structured in stock prices and focused on the implicit evaluation of the investor on taxable retained earnings and tax-free paid-in equity. Bond (et al., 2003) examined the effect of firm and shareholder tax, as well as 
Meade's (1978) $\mathrm{R}^{1}$ and $\mathrm{S}^{2}$ based tax flows, in light of uncertainty, default and shutting down. The study also shed light on issues related to tax avoidance.

Guenther and Sansing (2006) used a model that includes the investment and payout decisions of a company, in light of the investment options available to investors, in order to investigate how shareholder-level taxes are reflected in stock prices. In the model used, capitalization of tax is not eliminated by the presence of tax-exempt investors; further it does not depend on whether the equity is constituted by retain earning or contributed capital, nor by the taxation bracket of the hypothetical marginal investor. Leibrecht, Ballak and Wild (2009) explored the effect of dividend taxes on the dividends repatriated from foreign affiliates to their parent German firm. The study utilized Deutsche Bundesbank's firm-level data from Microdatabase Direct Investment (MiDi), on an augmented model of Lintner's dividend determination. The study focuses on cross-border intra-firm dividend payment in the manufacturing sector of wholly owned foreign affiliates. The research vindicated the Lintner Model, and the augmented Lintner model implied an increasing negative relationship between dividend taxes and the expected value of dividend repatriation.

\subsection{Dividends, Capital Structure, Cash Flow, Stock Price and Repurchase}

Many studies (Bank, Cheffina, \& Goergen, 2009; Corina, Mirela \& Mihaela, 2009; Dann, 1981; Gugler, 2003; Goergen, Renneboog, \& Correia da Silva, 2004; Skinner, 2008) have also analyzed the relationship between dividends, stock price, cash flow, debt structure, as well as repurchasing of stock. For example, Dann (1981) examined the response of repurchasing common stock on the value of the repurchasing company's common stock, debt and preferred stock. The study further examined the main causes of the valuation change. The primary factor identified is an informational signal from the repurchasing firm. Corina, Mirela and Mihaela (2009) investigated the amount of dividend to be paid out to investors by the firm, and the effect of the dividend policy on the stock price. The study also investigates a core area of finance, as it examines the management's dividend policy with the goal of valuation maximization for the shareholders, while creating adequate funds for the firm.

Sethi (1996) used a generalized form of the Miller-Modigliani (1961) framework to equate the stock price with the present value of future dividends. Blau and Fuller (2008) developed a model of corporate dividend policy and generated numerous testable predictions. The model is based on the notion that the management values operating flexibility. In stark contrast to UK and USA firms, German firms base their dividend on cash flow (Goergen, Renneboog, \& Correia da Silva, 2004) rather than on long run target payout ratios. In the German corporate scenario cash flow dictate dividend policy; published earnings do not form the basis of the dividend policy. This is a derivate of the conservative atmosphere of German accounting principles, coupled with the fact that published earnings do not accurately measure corporate performance, as German firms retain earnings to build legal reserves. Further, German Firms are ready to cut dividends in response to diminishing profitability, rather than the prevail policy of USA and UK firms to issue frequent small dividend payouts.

Gugler (2003) investigated the relationship between dividend policy, ownership and control structure of the firm. The study focused on Austrian firms during the period of 1991 - 1999. In a similar study, Gugler and Yurtoglu (2003) offer a new explanation of why dividends may be informative, based on empirical evidence from 736 dividend change announcements (for the period 1992 - 1998) of German firms. The study utilizes information on the ownership and control structure of German firms, in order to test the research hypothesis and compare it to the cash flow signaling explanation. Bank, Cheffina,

${ }^{1}$ Meade (1978) uses ' $\mathrm{R}$ ' to denote a corporate tax base including all transactions in real goods and services and financial services, but excluding financial transactions with shareholders (Chapter 12, p. 230).

${ }^{2}$ Meade (1978) uses ' $\mathrm{S}$ ' to denote a corporate tax base including only all financial transaction with shareholders (Chapter 12, p. 233). 
and Goergen (2009) augment Lintner's dividend determination model by focusing on the determinants of dividend policy in UK publicly listed corporations, during the period $1949-2002$. The enhanced models accommodate political factors; the model is tested using aggregate annual dividends and earnings data. The research found that that neither the political placement of the ruling party nor the regulations clearly stipulated to check corporate behavior were in accordance to theories of corporate governance dividend policy. This deviation in finding over a 53-year period is considerable significant, as it challenges many predictions of generally accepted corporate governance norms. Skinner (2008) investigated the relationship between earnings and dividend payout policy over the last three decades. The research identifies categories of dividend policy and concludes that the repurchases are currently the most popular form of payouts. Interestingly, the research points out that the classical dividend payout policy is now extinct.

\subsection{Country Specific Studies}

Dewenter, Warther, and Vincent (1998) compared Japanese and American company dividend policies; the Japanese firms were categorized into keiretsu, independent, and hybrid. The study examined the correlation between dividend changes and stock returns, and the reluctance to change dividends. Researchers have studied different aspect of dividends in numerous countries, using various statistical techniques. Mehar (2005) investigated corporate governance and dividend policy of 180 firms listed on the Karachi Stock Exchange for the period 1994 - 2001, using the Ordinary Least Square (OLS) technique. The study gives many discrete recommendations to the regulatory authorities, with regards to improving corporate governance and dividend policy (in the Pakistani context).

Franc-Dabrowska (2009) utilized descriptive statistics and financial analysis, as well as a fixed effect model to test the hypothesis that the firm's management minimizes dividend payments based on a hierarch theory, as it prefers internal avenues of financing economic growth opportunities. The study was interested in the hierarchy and substitution theories (of Capital Structure) as applied in dividend policy of Polish agriculture and foodstuff companies during the 2001 to 2006 period. Benzinho (2004) used panel data regressional, time-series and cross-sectional observations to estimate the Lintner model on firms that trade on the Portuguese Lisbon Stock Exchange (Euronext Lisbon). The study tests for stable smoothing dividend policy, which tend to be more characteristic of developed countries. Pang, $\mathrm{Yu}$, Troutt, and Hou (2008) developed a simulation-based approach to study the coefficient of variation of dividend yields, comparing the results with the traditional approach, using the Hang Seng index and its sub-indexes. Brooks and Helms (1990) developed a dividend discount model that allowed as many growth periods are required, using an equation that could easily be programmed, and provide prompt results. The study recommends the Newton-Rapson algorithm as a method for estimating the required rate of return.

\subsection{US Dividend Policy Different}

It is evident from the review of literature that while dividends are becoming scare in the US, in the rest of the world, both developed and emerging markets, dividends continue to play a significant part. Thus, it is important to ascertain the status of dividends in the US from a governance and tactical perspective, while also analyzing the alternative corporate governance perspective - retaining capital for investment. Once this is determined, the implications of such a reality will be analyzed in light of existing literature.

\section{Methodology}

\subsection{Data and Variable Description}

The research utilizes the balanced panel data set of 943 US listed corporation for the 2005 to 2009 time period of Mehboob (2019a). The data sample of 4,715 was derived from three sources, namely: Standard and Poors' Execucomp, Compustat Annual Financial database, and KLD Social Rating. The research will use the variables of the Mahboob (2019a): Pre-tax income (PI), Total annual director Remuneration (COMP), Good Corporate Governance (GCG), and Questionable Corporate Governance (QCG), in 
addition to the following variables: dividend (DVD), pretax income (PI), total revenue (REVT), investment (ICAPT), and market capitalization (MC). The description of the variables is:

COMP - The total annual director Remuneration is the total remuneration (salary, bonus and other perks) of all the executive (director, CEO or CFO) in a year for a listed firm.

DVD - dividend: total annual cash dividend issued by a firm. This is zero for many firms.

GCG - Good Corporate Governance: is a positive integer aggregate ( 0 to 15) of the following governance strengths: product, environment, human rights, community, employee relations, and corporate governance; zero signifying no corporate governance strengths.

ICAPT - The amount invested by the firm.

MC - Market capitalization: is the product of the stock price and the number of outstanding shares of a listed US firm.

PI - Pretax Income: the net income before the deduction of (income) tax.

QCG - Questionable Corporate Governance: is a positive integer aggregate (0 to 14) of the following governance concerns: product, environment, human rights, alcohol, tobacco, gambling, firearms, nuclear, employee relations, and corporate governance; zero signifying no corporate governance concerns.

REVT- The total sales revenue for the financial year.

\subsection{Balanced Panel Analysis Pretests}

Prior to conducting panel analysis, the following pretests are conducted: [i] multicollinearity, [ii] Breusch-Pagan LM, and [iii] Hausman test, after which panel analysis is conducted, using these three tests: [i] Pooled Ordinary Least Squares, [ii] fixed effect, and [iii] Weighted Least Squares.

\subsubsection{Multi-Collinearity}

Multicollinearity (Gujarati, 2004) is generally not an issue for panel data sets. Nevertheless, the data models were cleared of collinearity issues, as tabulated in Tables 4.1 and 4.2, well within the stipulated ten value.

TABLE 4.1: Corporate Tactics \& Governance Effect On Dividends

\begin{tabular}{|c|c|c|c|c|c|c|c|}
\hline \multirow{2}{*}{$\begin{array}{l}\text { Dependent Variable: } \\
\text { Dividend } \\
\text { Independent variables: }\end{array}$} & \multicolumn{4}{|c|}{ Model 1 (Governance Effect) } & \multicolumn{3}{|c|}{$\begin{array}{l}\text { Model } 2 \text { (Pro-Dividend } \\
\text { Tactics) }\end{array}$} \\
\hline & Coefficient & T-Stats & & VIF & Coefficient & T-Stats & \\
\hline $\begin{array}{l}\text { Good Corporate } \\
\text { Governance }\end{array}$ & $-3,130,543$ & -0.625 & $\dagger$ & 1.341 & & & \\
\hline $\begin{array}{l}\text { Questionable Corporate } \\
\text { Governance }\end{array}$ & $-6,489,106$ & -1.232 & $\dagger$ & 1.524 & & & \\
\hline All BOD Compensation & -0.214 & -0.348 & $\dagger$ & 1.384 & & & \\
\hline Intercept (constant) & $115,373,411$ & 10.390 & $*$ & & $1.02 \mathrm{E}+08$ & 12.052 & $*$ \\
\hline Market Capitalization & & & & 4.563 & -0.00046 & -0.659 & $\dagger$ \\
\hline Pretax Income & & & & 3.869 & 0.001053 & 0.162 & $\dagger$ \\
\hline Total Sales & & & & 2.406 & 0.000271 & 0.377 & $\dagger$ \\
\hline Invested Capital & & & & 2.343 & -0.00027 & -0.464 & $\dagger$ \\
\hline Time Periods & 5 & & & & 5 & & \\
\hline Cross-sections & 943 & & & & 943 & & \\
\hline Observations & 4,715 & & & & 4,715 & & \\
\hline
\end{tabular}




\begin{tabular}{lllll} 
Adjusted R-squared & 0.000 & & 0.000 & \\
F-Stats & 1.633 & $\dagger$ & 0.467 & $\dagger$ \\
Breusch-Pagan LM test & 0.735 & $\dagger$ & 0.677 & $\dagger$ \\
\hline
\end{tabular}

Notes: * indicates significance at $1 \%$ level. $\dagger$ indicate insignificance at more than $10 \%$ level.

\subsubsection{Breusch-Pagan LM Test}

The Breusch-Pagan LM test was conducted on the first two models (Table 4.1), indicating a preference for panel pooled estimates. The null hypotheses were accepted, indicating an insignificant variance $\left(\mathrm{V}_{\mathrm{i}}\right)$ across the cross-sections, which represent firms, with a chi-square value of less than one each. Thus, it can be safely assumed (Gujarat, 2004) that the data across different firms is not too different. However, the assumptions of the slope coefficients and constant intercepts are very restricted.

The Breusch-Pagan LM test on models 3 and 4 (Table 4.2) showed a preference for panel GLS (Generalized Least Squares). In these tests the null hypotheses were rejected, signifying a significant variance $\left(\mathrm{v}_{\mathrm{i}}\right)$ across the cross-sections, which represent firms, with high chi-square values (Table 4.2), at a significance level of less than $1 \%$.

\subsubsection{Hausman Test}

The consistency of the GLS models 3 and 4 was probed by the Hausman test (Hausman 1978). The Hausman test indicated that a GLS fixed effect model (Table 4.2) will be more consistent (with a chisquared values of about 242 and 393, at a significance level of less than 1\%), as per Equation 1:

$\mathrm{y}_{\mathrm{it}}=\mathrm{X}_{\mathrm{it}} \beta_{1}+\mathrm{X}_{\mathrm{it}} \beta_{2}+\mathrm{X}_{\mathrm{it}} \beta_{3}+\mathrm{u}_{\mathrm{it}}$

Where $\mathrm{y}_{\mathrm{it}}$ is the dependent variable - invested capital during the period $t$ for the firm $i$ (cross-section); $\mathrm{X}_{\mathrm{it}}$ is a vector of independent variables for the period $t$ and firm $i ; \beta_{1}$ is a $k \mathrm{x} 1$ vector of parameters, $\mathrm{u}_{\mathrm{it}}$ and is an error or distribution term specific to $i$ firms in time period $t$.

For a fixed effect model, the unitary pooled error term $\left(\mathrm{u}_{i t}\right)$ is decomposed into a unit specific and timeinvariant component $\left(\alpha_{i}\right)$ and $\varepsilon_{i t}$ an observational specific error (Equation 2):

$\mathrm{y}_{\mathrm{it}}=\mathrm{X}_{\mathrm{it}} \beta_{1}+\alpha_{\mathrm{i}}+\varepsilon_{i t}$

$\mathrm{u}_{\mathrm{it}}$ (Equation 1) is decomposed into a unit-specific and time-invariant component $\alpha_{\mathrm{i}}$, and an observation-specific error $\varepsilon_{i t}$. When estimating unit-specific y-interests, the $\alpha_{\mathrm{i}}$ s are considered fixed parameters. Thus, the group effect hypothesis is not tested in fixed effect models; estimation of the remaining parameters is made. As a result, the effect of time-invariant regressors are ignored.

TABLE 4.2: Corporate Tactics \& Governance (Using Fixed Effect) On Investment

\begin{tabular}{|c|c|c|c|c|c|c|}
\hline \multirow{2}{*}{$\begin{array}{l}\text { Dependent Variable: } \\
\text { Investment } \\
\text { Independent variables: }\end{array}$} & \multicolumn{4}{|c|}{$\begin{array}{l}\text { Model 3a (Governance } \\
\text { Effect) }\end{array}$} & \multicolumn{2}{|c|}{$\begin{array}{l}\text { Model 4a (Pro- } \\
\text { Investment Tactics) }\end{array}$} \\
\hline & Coefficient & T-Stats & & VIF & Coefficient & T-Stats \\
\hline $\begin{array}{l}\text { Good Corporate } \\
\text { Governance }\end{array}$ & $414,375,383$ & 3.086 & $*$ & 1.341 & & \\
\hline $\begin{array}{l}\text { Questionable Corporate } \\
\text { Governance }\end{array}$ & $589,527,444$ & 4.030 & $*$ & 1.524 & & \\
\hline All BOD Compensation & 35.571 & 3.668 & $*$ & 1.384 & & \\
\hline Intercept (constant) & $3,556,700,529$ & 12.030 & $*$ & & $1.92 \mathrm{E}+09$ & 10.798 \\
\hline
\end{tabular}




\begin{tabular}{llllll} 
Market Capitalization & & 3.843 & -0.0168 & -1.432 & $\dagger$ \\
Pretax Income & & 3.83 & -0.28009 & -3.854 & $*$ \\
Total Sales & & 2.066 & 0.574558 & 24.116 & $*$ \\
Time Periods & 5 & & & 5 & \\
Cross-sections & 943 & & 943 & \\
Observations & 4,715 & & 4,715 & \\
& & & & \\
Adjusted R-squared & 0.947 & & & 0.953 & \\
F-Stats & 89.568 & $*$ & & 102.917 & $*$ \\
Breusch-Pagan LM test & $7,628.760$ & $*$ & & $6,639.840$ & $*$ \\
Hausman test & 242.143 & $*$ & & 393.337 & $*$ \\
\hline
\end{tabular}

Notes: * indicates significance at $1 \%$ level. $\dagger$ indicate insignificance at more than $10 \%$ level. (Source: Authors estimation)

\subsection{Pooled Ordinary Least Squares - Models 1 and 2}

All 4,715 observations are analyzed in a common regression, regardless of the variation that may arise from different time periods. Thus, pooled regression (Gujarati, 2004:280) assumes the same intercept and slope coefficient remains the same for all five years.

The effect of corporate governance on dividends was tested by taking the three corporate governance variables - (i) the board of directors' compensation (COMP), (ii) GCG and (iii) QCG, as the regressors, and dividend as the regressand using pooled regression (as determined in equation 1):

$$
\mathrm{DVDit}=\alpha_{\mathrm{i}}+\mathrm{GCG}_{\mathrm{it}} \beta_{\mathrm{GCG}}+\mathrm{QCG}_{\mathrm{it}} \beta_{\mathrm{QCG}}+\mathrm{COMP}_{\mathrm{it}} \beta_{\mathrm{COMP}}+\varepsilon_{i t}
$$

Equation 3a (above) can be rewritten with its coefficients as (Equation $3 \mathrm{~b}$ ):

$\mathrm{DVD}=115,373,411-3,130,543 \dagger(\mathrm{GCG})-6,489,106 \dagger(\mathrm{QCG})-0.214 \dagger(\mathrm{COMP})(3 \mathrm{~b})$

The effect of corporate tactics on dividends was tested by taking the four tactical variables with firms tend to focus on optimizing: - (i) the market capitalization of the firm (MC), (ii) pretax income (PI) (iii) total sales (REVT) and (iv) and invested capital (ICAPT), as the regressors, and dividend as the regressand using pooled regression (as determined in equation 1):

$$
\mathrm{DVDit}=\alpha_{\mathrm{i}}+\mathrm{MC}_{\mathrm{it}} \beta_{\mathrm{MC}}+\mathrm{PI}_{\mathrm{it}} \beta_{\mathrm{PI}}+\mathrm{REVT}_{\mathrm{it}} \beta_{\mathrm{REVT}}+\mathrm{ICAPT}_{\mathrm{it}} \beta_{\mathrm{ICAPT}}+\varepsilon_{i t}
$$

Equation $4 \mathrm{a}$ (above) can be rewritten with its coefficients as (Equation $4 \mathrm{~b}$ ):

$$
\mathrm{DVD}=102,085,050-0.00046 \dagger(\mathrm{MC})+0.00105 \dagger(\mathrm{PI})+0.00027 \dagger(\mathrm{REVT})-0.00027 \dagger(\mathrm{ICAPT})(4 \mathrm{~b})
$$

Both models point to the same results, with different coefficients: none of the independent variables has any significant effect on dividends. If anything, all three corporate governance variables have a negative and insignificant effect on dividend; QCG more than twice the negative (yet insignificant) effect than GCG on dividend. Likewise, in line with theory both firm valuation and investment have negative and insignificant effect on dividend; sales and profitability have positive and insignificant effect. All regressors in both models have an insignificant effect on dividend, rendering both models insignificant, in addition to offering very little explanation for changes in dividend.

\subsection{Panel Analysis using GLS}

Using OLS would be inefficient for panel data analysis (Baltagi, 1995), as the data set does not fulfill the assumptions of the Gauss-Markov theorem. GLS is more robust in providing coefficient estimates for simple cross-section or time series (Gujrati, 2004), apart from minimizing the bias into broad 
aggregates, which are primarily due to the large number of firms - 943; it is more informative and variable, with more degrees of freedom, and less collinearity issues (Gujrati, 2004); it is more apt to analyzing the dynamics of changes that arise due to repetition of cross-sectional observations. Further, the covariance structure of the error term can be probed with greater efficiency, making the technique the most suitable under the circumstances (Gujrati, 2004). Nevertheless, one must know the limitations and drawback of panel analysis; fortunately, the analysis only includes three independent variables.

The effect of corporate governance on investment was tested by taking the three corporate governance variables - (i) the board of directors compensation (COMP), (ii) GCG and (iii) QCG, as the regressors, and invested capital as the regressand using fixed effect (as determined in equation 2):

$$
\mathrm{ICAPT}_{\mathrm{it}}=\alpha_{\mathrm{i}}+\mathrm{GCG}_{\mathrm{it}} \beta_{\mathrm{GCG}}+\mathrm{QCG}_{\mathrm{it}} \beta_{\mathrm{QCG}}+\mathrm{COMP}_{\mathrm{it}} \beta_{\mathrm{COMP}}+\varepsilon_{i t}
$$

Equation $5 \mathrm{a}$ (above) can be rewritten with its coefficients as (Equation $5 \mathrm{~b}$ ):

$$
\mathrm{ICAPT}=3,556,700,529+414,375,383(\mathrm{GCG})+589,527,444(\mathrm{QCG})+35.57(\mathrm{COMP})
$$

The $\mathrm{X}_{\mathrm{it}} \mathrm{s}$ and $\beta$ s of Equation 2 are replaced by the respective independent variables, GCG, QCG and COMP, as given in Equations $5 \mathrm{a} \& 5 \mathrm{~b}$. The dependent $\mathrm{y}_{\text {it }}$ is replaced by ICAPT $\mathrm{it}_{\text {. }}$

The effect of corporate tactics on investment was tested by taking the three variables - (i) market capitalization of the firm (MC), (ii) pretax income (PI), and (iii) total sales revenue (REVT), as the regressors, and invested capital as the regressand using fixed effect (as determined in equation 2):

$$
\mathrm{ICAPT}_{\mathrm{it}}=\alpha_{\mathrm{i}}+\mathrm{MC}_{\mathrm{it}} \beta_{\mathrm{MC}}+\mathrm{PI}_{\mathrm{it}} \beta_{\mathrm{PI}}+\mathrm{REVT}_{\mathrm{it}} \beta_{\mathrm{REVT}}+\varepsilon_{\text {it }}
$$

Equation 6a (above) can be rewritten with its coefficients as (Equation 6b):

$$
\text { ICAPT }=1,920,877,936-0.0168(\mathrm{MC})-0.28(\mathrm{PI})+0.5746(\mathrm{REVT})
$$

The $\mathrm{X}_{\mathrm{it}} \mathrm{s}$ and $\beta \mathrm{s}$ of Equation 2 are replaced by the respective independent variables, MC, PI and REVT, as given in Equations $6 a$ and $6 b$. The dependent $y_{i t}$ is replaced by ICAPT it. $_{\text {. }}$

\subsection{Weighted Least Squares (WLS)}

For robust estimation, free of any unknown heteroscedastic that may arise in panel fixed effect (Stock \& Watson, 2008) models (Equation $5 \& 6$ ), especially since the time span is more than two years (with numerous firms), Weighted Least Squares estimation (Greene, 2002; Gujarati, 2004) would be appropriate. Thus, Equations 5 and 6 are tested using Weighted Least Squares (WLS), give the following results with their respective coefficients (Equations $7 \mathrm{~b} \& 8 \mathrm{~b}$ ):

$$
\mathrm{ICAPT}=-12,535,000,000+2,044,760,000(\mathrm{GCG})+6,280,770,000(\mathrm{QCG})+266.89(\mathrm{COMP})
$$

$$
\mathrm{ICAPT}=-342,975,000+0.346(\mathrm{MC})-0.605(\mathrm{PI})+0.363(\mathrm{REVT})
$$

Both models (Table 4.3) as well as all six variables in them are significant at $1 \%$, with decent chi-square values.

\subsection{Rigorous Empirical Scrutiny}

To ensure robust scrutiny of the investment models, rigorous statistical diagnostics will be used in addition to WLS (Stock \& Watson, 2008); heteroskedasticity-free analysis, granger causality, LOESS Locally estimated Scatterplot Smoothing (Cleveland \& Delvin, 1986) and goodness of fit selection (Akaike, 1974; Akaike, 1985; Boisbunon, Canu, Fourdrinier, Strawderman \& Well, 2014) and comparative parameters for selecting better models. 


\section{Results}

Figure 4.1: Factors Preventing Dividend Policy

The superficial dividends by US listed firms are a consequence of the board of directors, the firms' good and questionable governance, market valuation, pre-tax income, and investment, although in an insignificant way; the negative effect of questionable governance and market value play a significant role in curbing dividends. Only sales have a positive and significant influence on fostering a dividend policy.

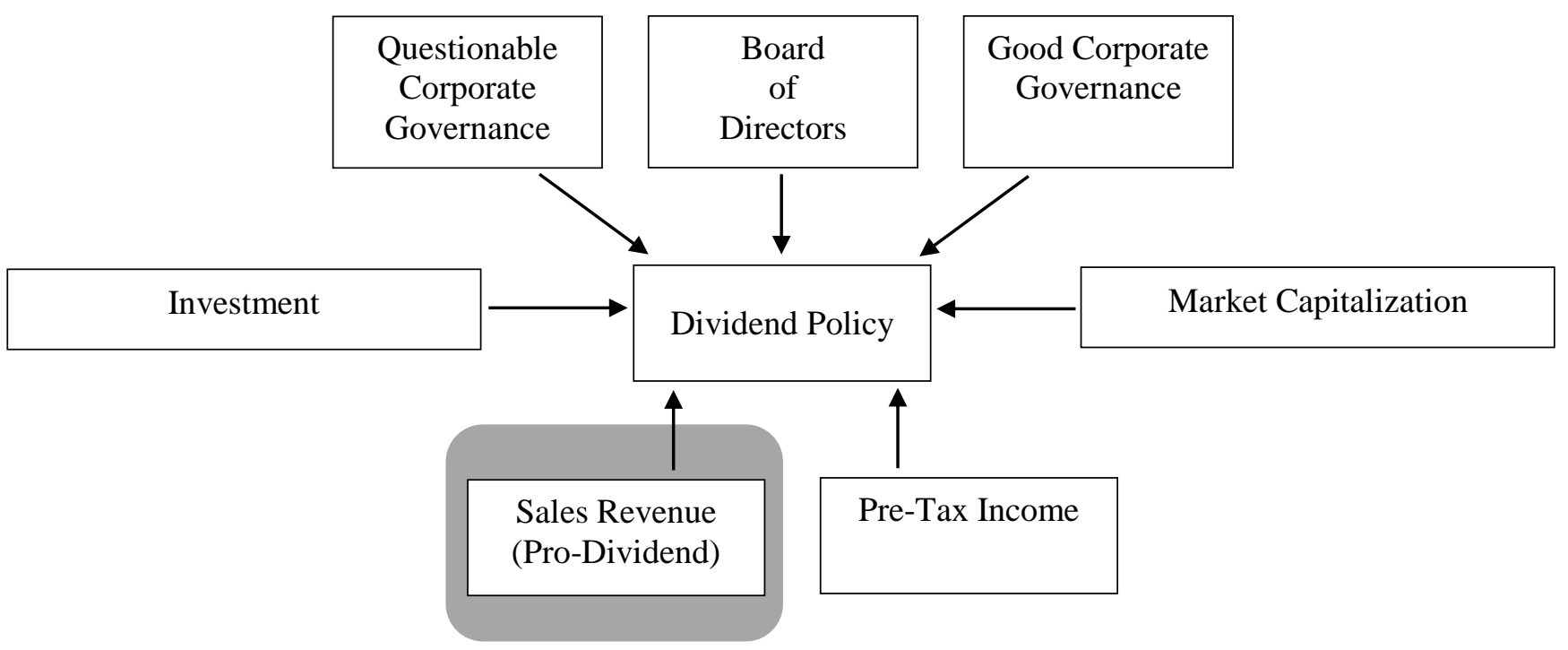

Figure 4.2: Factors Influencing Investment

Investment decisions by US listed firms are a consequence of the board of directors, the firms' good and questionable governance, market capitalization and sales revenue; pre-tax profits hamper investments, possibly in favor of expensing preference.

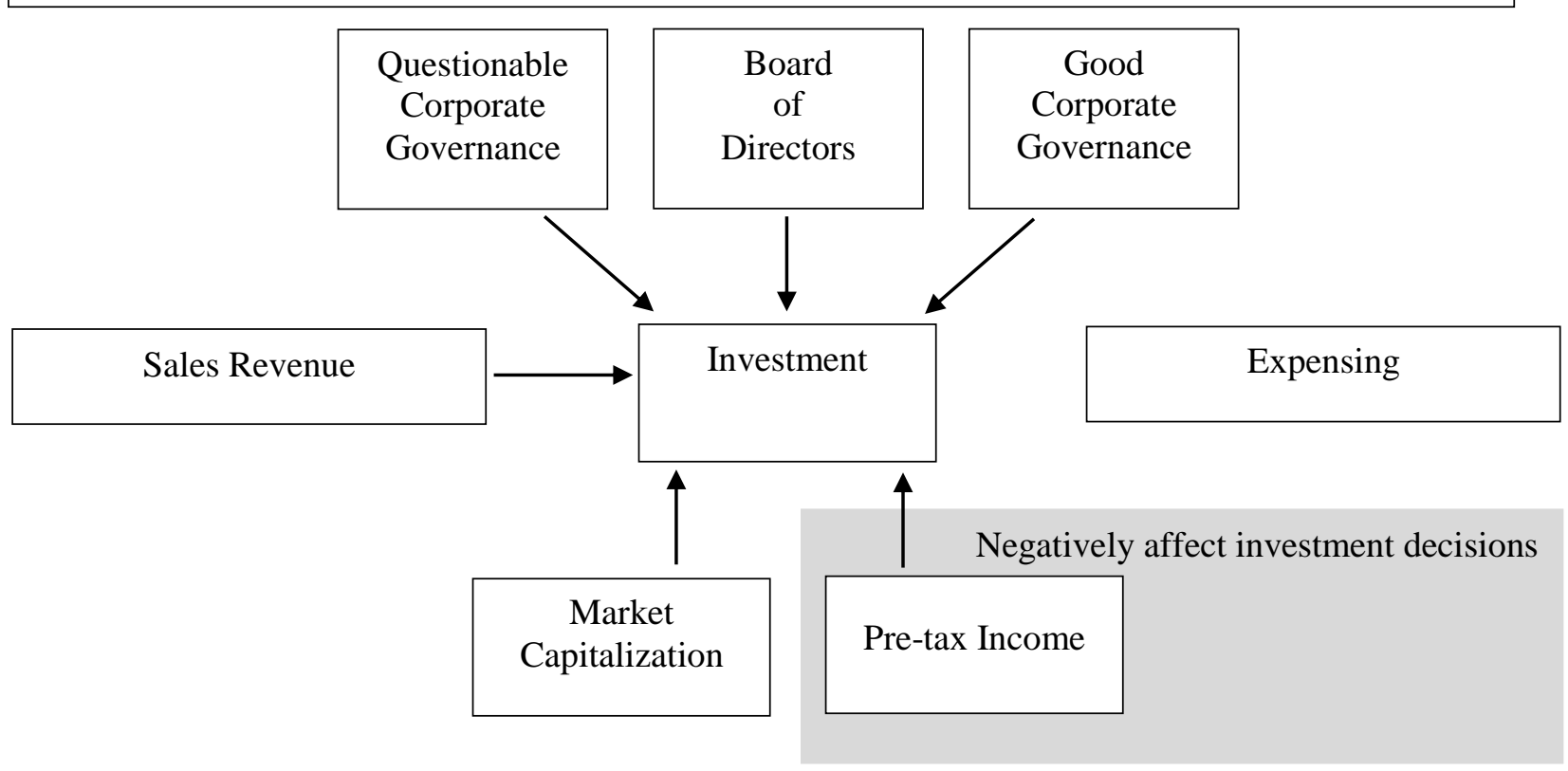


Table 4.3: Corporate Tactics \& Governance (Using Weighted Least Squares-Wls) On Investment

\begin{tabular}{|c|c|c|c|c|c|c|}
\hline $\begin{array}{l}\text { Dependent Variable: } \\
\text { Investment }\end{array}$ & \multicolumn{3}{|c|}{ Model 3b (Governance Effect) } & \multicolumn{3}{|c|}{ Model 4b (Tactics Effect) } \\
\hline Independent variables: & Coefficient & T-Stats & & Coefficient & T-Stats & \\
\hline $\begin{array}{l}\text { Good Corporate } \\
\text { Governance }\end{array}$ & $2,044,760,000$ & 8.201 & $*$ & & & \\
\hline $\begin{array}{l}\text { Questionable Corporate } \\
\text { Governance }\end{array}$ & $6,280,770,000$ & 23.360 & $*$ & & & \\
\hline All BOD Compensation & 266.892 & 14.170 & $*$ & & & \\
\hline Intercept (constant) & $-12,535,000,000$ & -15.230 & $*$ & $-3.43 E+08$ & -27.945 & $*$ \\
\hline Market Capitalization & & & & 0.346 & 58.173 & $*$ \\
\hline Pretax Income & & & & -0.605 & -12.535 & $*$ \\
\hline Total Sales & & & & 0.363 & 76.041 & $*$ \\
\hline Time Periods & 5 & & & 5 & & \\
\hline Cross-sections & 916 & & & 943 & & \\
\hline Observations & 4,580 & & & 4,715 & & \\
\hline Adjusted R-squared & 0.272 & & & 0.792 & & \\
\hline F-Stats & 634.098 & $*$ & & $5,987.623$ & $*$ & \\
\hline
\end{tabular}

\subsection{US Firms - Pro-Investment and Dividend Avoidance Preference}

In line with the residual and pecking order theories of dividends, US corporate governance positively and significantly influence investment decision(s); Table 4.8 summarizes the results. These investment decisions (Table 4.2 -Model 3a; Table 4.3 - Model 3b; Table 4.5 - Models 5a \& 5b; Figure 4.2) by the board of directors are reflected in their decision to abandon cash dividend (Table 4.1 - Model 1a; Table 4.6 - Model 6; Table 4.7-Model 7a \&7b; Figure 4.1). Results clearly establish an insignificant and negative effect of corporate governance on dividends (Table 4.1 -Model 1; Table 4.6 - Model 6). Thus, it is clear that corporate directors follow a pro-investment strategy (Table 4.2 -Model 3a; Table 4.5 Model 5a \& 5b), at the expense of dividend (Table 4.1 - Model 1; Table 4.6 - Model 6; Table 4.7 Models $7 \mathrm{a} \& 7 \mathrm{~b}$ ) - practically making cash dividend extinct; Graph 4.1 depicts the inverse relation between dividends and investment. This corporate governance approach in the US may be, simply because the directors (Rose, 2007; Kumar \& Zattoni, 2018) are legally bound to safeguard their investors' interests and pursue a policy to maximize internally generated fund for investment. Further, the role of managerial skills (García-Sánchez \& García-Meca, 2018) in formulating ideal investment pronouncements cannot be over stressed; indeed, their skills and knowledge base play a major role.

Rigorous econometric data scrutiny (Table 4.1; Table 4.6) confirm that the board of directors, good and questionable governance oppose dividends. While the negative influence of the board and good governance is insignificant, the curbing influence of questionable governance is profound; likewise, profitability and firm value also opposes dividend, as is evident for the WLS and heteroskedasticity free model (Table 4.5-Model 5a \& 5b; Model 4.7 -Models 7a \& 7b), after accounting for goodness of fit scrutiny, when determining model selection (Akaike, 1974; Akaike, 1985; Boisbunon, Canu, Fourdrinier, Strawderman \& Well, 2014). If anything, the latent support of sales revenue supports the argument for dividends. Thus, in line with theory if availability of funds permit, dividend might be considered, as evident by the scanty superficial dividends by some firms. 


\section{Graph 4.1: Dividend \& Investment Inverse Relationship (LOESS Fit)}

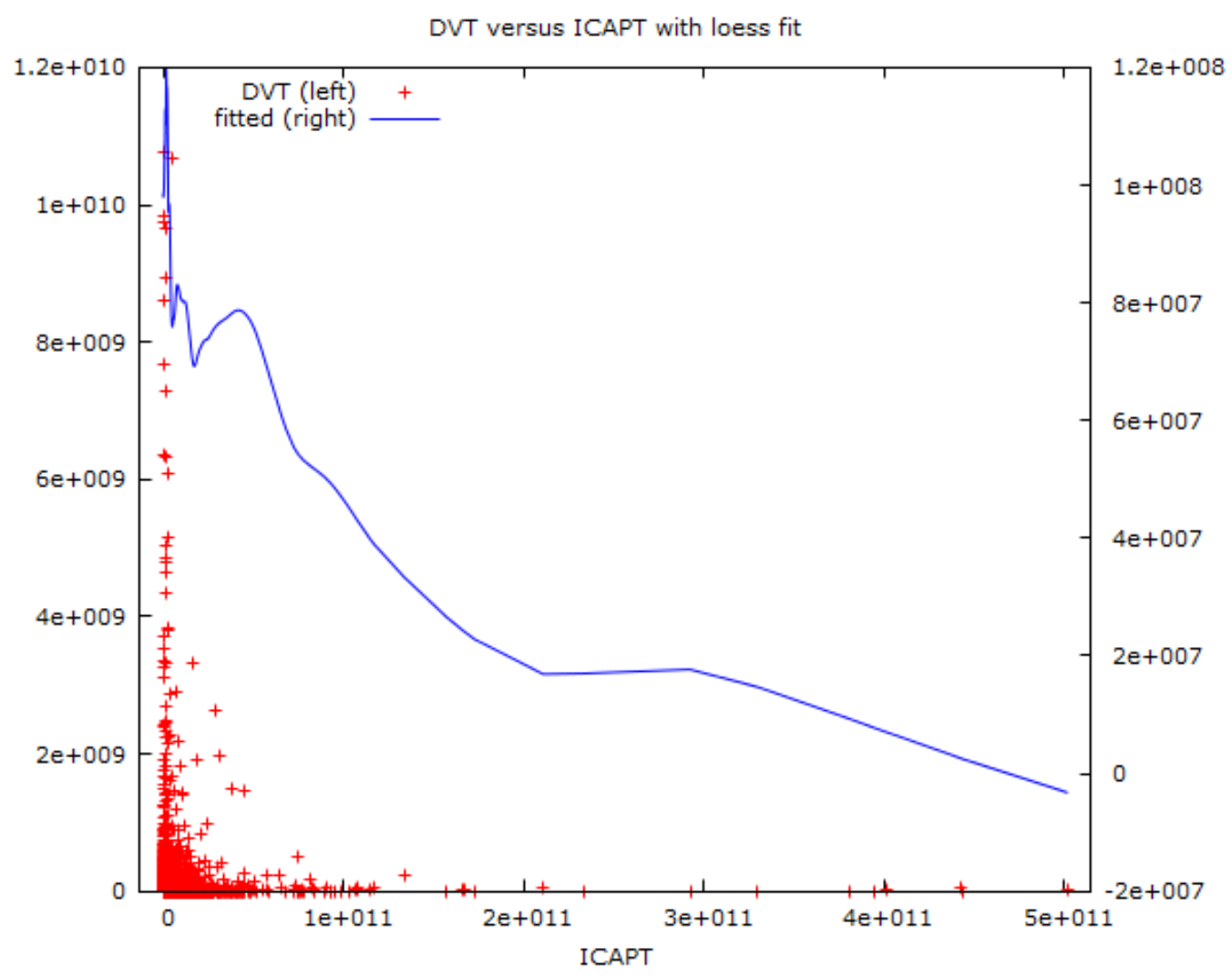

The corporate governance of US firms clearly exhibits a significant appetite for investment of capital (Table 4.2 - Model 3a; Table 4.3 - Model 3b). While the fixed effect model (3a, Equation 5) exhibits a somewhat codominant effect of good and questionable governance on investment, the WLS model ( $3 \mathrm{~b}$, Equation 7) reveals a recessive effect of good corporate governance in the presence of dominant effect of questionable governance on investment; questionable corporate governance has a three times greater effect on investment, as compared to good corporate governance.

Table 4.6: Unravelling the US Dividend Puzzle

\begin{tabular}{|c|c|c|c|}
\hline \multicolumn{2}{|c|}{ Dependent Variable: Investment } & \multicolumn{2}{|c|}{$\begin{array}{l}\text { Model } 6 \text { (Heteroskedasticity- } \\
\text { corrected, } 4715 \text { observations) }\end{array}$} \\
\hline Independent variables: & Coefficient & T-Stats & \\
\hline const & $112,770,140$ & 12.258 & $*$ \\
\hline GCG & $-901,504$ & -0.342 & $\dagger$ \\
\hline QCG & $-6,522,518$ & -2.577 & $*$ \\
\hline BOD Compensation & -0.284 & -1.065 & $\dagger$ \\
\hline \multicolumn{4}{|c|}{ Statistics based on the weighted data } \\
\hline Adjusted R-squared & 0.006 & Akaike criterion & 29639.81 \\
\hline $\mathrm{F}(3,4711)$ & 9.705 & Schwarz criterion & 29665.64 \\
\hline P-value(F) & $2.21 \mathrm{E}-06$ & Hannan-Quinn & 29648.89 \\
\hline
\end{tabular}

Notes: * indicates significance at $1 \%$ level. $\dagger$ indicate insignificance at more than $10 \%$ level.

Results are further strengthened (Cleveland \& Delvin, 1988) by Locally estimated Scatterplot Smoothing (LOESS) graphical representation (Graph 4.1), which depicts an inverse relationship 
between dividends and investment, with few firms opting in favor of dividends. The use of LOESS is justified by the relatively large dataset (Cleveland \& Delvin, 1988).

\subsection{Management Flexibility and Dividends}

Researchers have long documented corporate management preference for flexibility, especially with more (retained) capital and a preference for dividendless policy. Blau and Fuller's (2008) model of corporate dividend policy generated testable predictions. Management generally values flexibility; flexibility depend on operating cash; the availability of which is maximized in the absence of dividends. While the ability to invest in opportunistic growth projects is enhances, it costs shareholders in terms of reduced share prices. Franc-Dabrowska (2009) found that the management of the firm minimizes dividend payment based on the hierarchy theory, as it prefers to use internally generated funds for growth opportunities. In 1936, in spite of the incentives shaped (Christie \& Nanda, 1994) by unexpected federal tax on retained income, the growth of dividends was lower in firms associated with higher agency costs. Nevertheless, the fundamental role managerial skills and expertise have in accomplishing investment initiatives is vital, as confirmed by recent empirical research (García-Sánchez \& García-Meca, 2018). Empirical results confirm earlier findings (Tables 4.1 - 4.6), that managers prefer flexibility to retain dividends.

\subsection{US Governance follow a Pro-Investment Preference under Influence of QCG}

Jensen, Solberg and Zorn (1992) empirically proved that when high insider ownership prevails in the firm, debt and dividends are lower. In order to keep out potential investors and lenders from meddling (Corina, Mirela and Mihaela, 2009) with the governance of the firm, the management prefers to build mountain of retained earnings for investment opportunities, thus minimizing or avoiding dividends; our research findings strengthens these earlier researches (Tables 4.1, 4.2 \& 4.3). Interestingly, questionable governance when compared to good governance have a more profound influence on investment; according to Equation 5 by a factor of about 1.4, and three times according to Equation 7 . It would seem that questionable governance practices exert more influence than good governance, possibly resulting in more accumulated retained earnings, transforming into pyramids of capital. Thus, in this regard retaining profits for reinvestment, it would seem that questionable corporate governance seems dominant; good corporate governance is recessive. Presumable the superior skills of managers may possibly be influencing investments, under the latent guise of questionable governance.

Table 4.7: Unravelling the US Dividend Puzzle

\begin{tabular}{lllll}
\hline $\begin{array}{l}\text { Dependent Variable: } \\
\text { Dividend }\end{array}$ & $\begin{array}{l}\text { Model 7a (Heteroskedasticity- } \\
\text { corrected) }\end{array}$ & \multicolumn{2}{l}{$\begin{array}{l}\text { Model 7b (Panel Weighted least } \\
\text { Squares) }\end{array}$} \\
Independent variables: & $\begin{array}{l}\text { Coefficient } \\
\text { Coefficient }\end{array}$ & T-Stats & T-Stats \\
\hline
\end{tabular}

Using 4715 observations (943 cross-sectional firms \& 5 time periods)

$\begin{array}{lrrrrrl} & & & & \text { Weights based on per-unit error variances } \\ \text { const } & 101484791.3 & 12.40782 & * & 30934722.58 & 26.38556 & * \\ \text { ICAPT } & -5.60 \mathrm{E}-05 & -0.17506 & \dagger & -5.99 \mathrm{E}-05 & -1.60703 & \dagger \\ \text { MC } & -0.000323604 & -0.90178 & \dagger & -0.000109136 & -2.06469 & * * \\ \text { PI } & 0.000535878 & 0.118321 & \dagger & -0.000299861 & -0.45008 & \dagger \\ \text { REVT } & -7.23 \mathrm{E}-05 & -0.11282 & \dagger & 0.000179698 & 1.951019 & * *\end{array}$

Statistics based on the weighted data

$\begin{array}{lrr}\text { Adjusted R-squared } & 0.000524034 & 0.006935958 \\ \mathrm{~F}(4,4710) & 1.617897596 & 9.231117502 \\ \mathrm{P}-\text { value(F) } & * & *\end{array}$




\begin{tabular}{lll} 
Akaike criterion & 29957.45099 & 10463.18984 \\
Schwarz criterion & 29989.74351 & 10495.48236 \\
Hannan-Quinn & 29968.80271 & 10474.54157 \\
\hline Notes: * indicates significance at $1 \%$ level; $* *$ at $5 \%$ level. $\dagger$ indicate insignificance at more than $10 \%$ level.
\end{tabular}

Figure 4.3: Corporate Governance Preference

The Corporate Governance preference of US listed firms is to avoid dividend payout, in preference of investments. Questionable governance plays a dominant role, while good corporate governance plays a recessive role in curbing cash dividends.

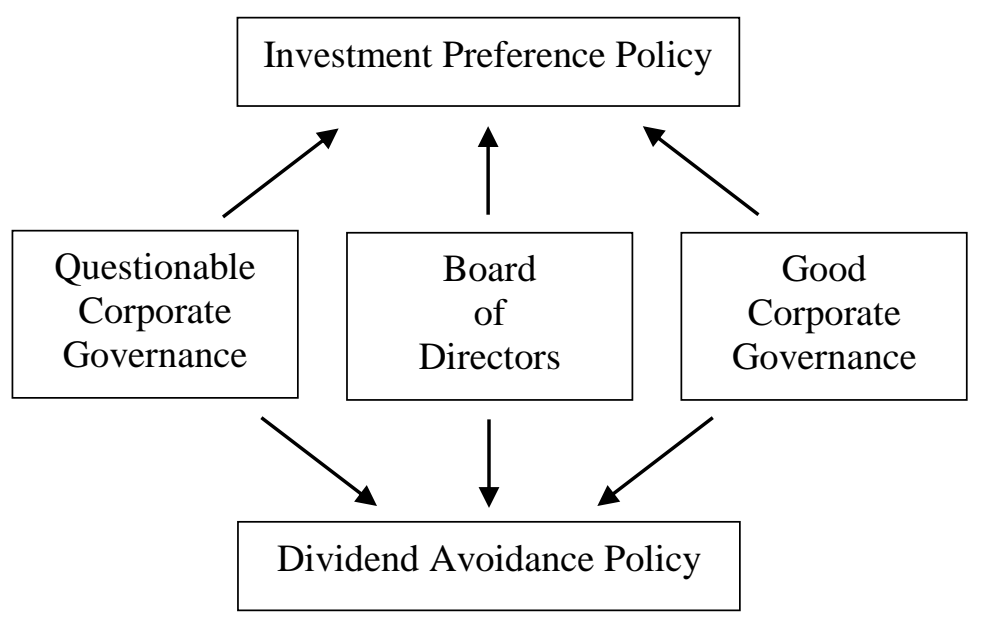

\subsection{Revenues Boost Investment}

The corporate tactics used demonstrate a significant effect on investment of capital (Table 4.2 - Model 4a; Table 4.3 - Model 4b; Table 4.5 - Model 5a \& 5b; Figure 4.2; Graph 4.2). Managers tend to boost sales which tends to also boost investments; investments boost sales, establishing a positive bidirectional spiraling relationship. This phenomenon is confirmed by the two way pairwise Granger Causality test (Table 4.4), LOESS graph (Graph 4.2) as well as Pearson coefficient correlation. The coefficient correlation test value of about 0.68 at $1 \%$ significance level is established by the Pearson test, between sales and investment; this would be classified (Buda \& Jarynowski, 2010; Weathington, Cunningham, \& Pittenger, 2012) in the high positive correlation category. These empirical results suggest a high positive bidirectional correlation between investment and sales. Thus, it is not surprising to find capital pyramids that eventually turn into monopolized capital, controlling numerous companies; pursuing the pecking order theory leads to capital monopoly. The sales/investment paradigm may also stem for the superior investment decision making skills of managers (García-Sánchez \& García-Meca, 2018). 


\section{Graph 4.2: Investment \& Pre-Tax Income Relationship (LOESS Fit)}

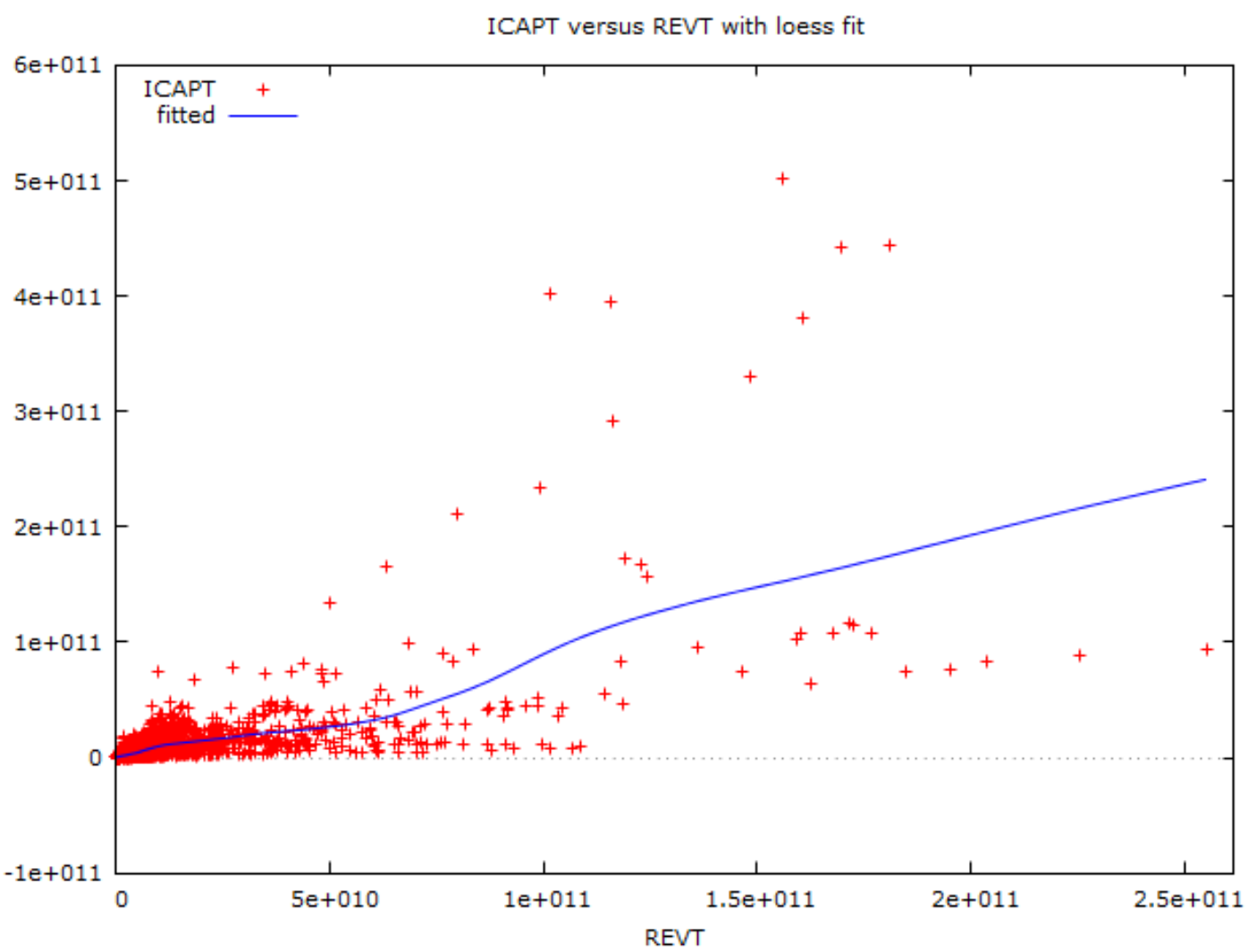

Table 4.4: Bidirectional Granger Causality Between Revenue \& Investment

Pairwise Granger Causality Tests (2005 -2009, $1^{\text {st }}$ lag)

Null Hypothesis:

Obs F-Statistic Prob.

TOTAL SALES does not Granger Cause INVESTMENT

3772

12.226

INVESTMENT does not Granger Cause TOTAL SALES

59.806

Notes: * indicates significance at $1 \%$ level. (Source: Authors estimation)

\subsection{Market Capitalization and Investment}

In 1962, Gordon (1962) empirically analyzed the neoclassic theory of corporate investment to achieve the corporate objective - maximize shareholder value, establishing a positive relationship. However, later researchers (Jensen, 1986; Griffin, 1988) argued that excess availability of fund to managers leads to unwise investment decisions, which in turn damage the firm's valuation. Strong and Meyers (1989) report a negative relationship between discretionary investment and investor returns price in the US paper industry; however, a positive link was established between investment (acquisition) and valuation. Similarly, our results seem a bit murky initially. An increase in the market value of the corporation seems to have a negative (Table 4.2 - Model 4a; Figure 4.2), but insignificant effect on investment. However, the more robust WLS estimation (Table 4.3 - Model 4b; Table 4.5 - Model 5a \& 5b) and heteroskedasticity-corrected model reveals that the firm's market capitalization has a significant positive effect on investment. In line with previous studies, the firms market capitalization increases investment. In retrospect of the rigorous empirical tests, it is difficult to validate (García-Sánchez \& García-Meca, 2018), that with increased market capitalization, managers in their investment decisions might become a bit complacent, but our framework is not designed to highlight such subtle latent relationships. 
Table 4.5: Unravelling the US Investment Puzzle

\begin{tabular}{lllll}
\hline $\begin{array}{l}\text { Dependent Variable: } \\
\text { Investment }\end{array}$ & $\begin{array}{l}\text { Model 5a (Heteroskedasticity- } \\
\text { corrected) }\end{array}$ & $\begin{array}{l}\text { Model 5b (Panel Weighted least } \\
\text { Squares) }\end{array}$ \\
Independent variables: & $\begin{array}{l}\text { Coefficient } \\
\text { Coefficient }\end{array}$ & T-Stats & T-Stats \\
\hline
\end{tabular}

Using 4715 observations (943 cross-sectional firms \& 5 time periods)

Weights based on per-unit error variances

$\begin{array}{lcccccc} & \text { coefficient } & \text { t-ratio } & \text { coefficient } & \text { t-ratio } & \\ \text { Const } & -14,250,814 & -0.410 & \dagger & -342,975,161 & -27.945 & * \\ \text { PI } & -1.274 & 16.666 & * & -0.605 & -12.535 & * \\ \text { REVT } & 0.281 & 22.761 & * & 0.363 & 76.041 & * \\ \text { MC } & 0.562 & 50.619 & * & 0.346 & 58.173 & *\end{array}$

Statistics based on the weighted data

\begin{tabular}{|c|c|c|}
\hline Adjusted R-squared & 0.661 & 0.792 \\
\hline $\mathrm{F}(3,4711)$ & 3,065 & 5,987 \\
\hline
\end{tabular}

\begin{tabular}{lll} 
Akaike criterion & 20,578 & 11,337 \\
Schwarz criterion & 20,604 & 11,363 \\
Hannan-Quinn & 20,588 & 11,346 \\
\hline
\end{tabular}

Notes: * indicates significance at $1 \%$ level. $\uparrow$ indicate insignificance at more than $10 \%$ level.

\subsection{Profits Diminish Investments}

The research empirical findings suggest that profits (Table 4.2, Model 4a; Table 4.3 -Model 4b; Figure 4.2; Table 4.5 - Models $5 \mathrm{a} \& 5 \mathrm{~b}$ ) tend to have a significant negative effect on investment (Fazzari and Petersen, 1993); probably focusing more on operating capital. This could be because investor tend to be short sighted at times, and prefer delaying capital expenditures, while favoring short term operating capital strategies, that may involve tax deductible loans which are instrumental in bringing down the weighted average cost of capital.

However, corporate US profitability has a significant negative effect on investment (Table 4.2 - Model 4a; Table4.3 - Model 4b; Table 4.5 -Model 5a \& 5b; Figure 4.2); the more robust panel WLS reveals that profitability tends to reduce investment by about twice as much - about $60 \%$, while the heteroskedascastic-corrected model suggests hampering investment by $120 \%$. This would suggest that the overwhelming corporate governance policy is not to invest profits; in fact, empirical results would suggest that profits decrease investment.

Fazzari and Petersen (1993) while investigating the neglected role of working capital had interesting findings. Since working capital competes with fixed investment, from a pool of finance, the coefficient of endogenous working capital is negative for fixed-investment regression. In the short term, working capital is used to smooth fixed investment, thus many studies have reported a constraint on growth and investment.

So, what happens to profits if they are not invested or given as dividend to investors? The only plausible explanation would be that profits are expensed off where tax deductible, in order to avoid 
taxation. Some profits may be expensed off as (Coffee 2005; Denis, Hanouna \& Sarin, 2006) incentive, perks, bonuses to executives, and stock options (Boumosleh, 2009) especially if they happen to be major investors as well. Conyon and He (2012) document a clear positive connection between CEO remuneration and corporate profit and market capitalization. In the Japanese scenario, Colpan and Yoshikawa (2012) report a direct link between executive bonuses and profit; Sakawa, Moriyama and Watanabel (2012) relate that incentive-based compensation to be more effective for firms with more foreign investors.

\subsection{Capitalization and Expensing Latent Ploy?}

Empirical results seem to point towards a latent ploy by the firm's higher echelons, gaining from the virtues of investment capitalization as well as the benefits of tax-deductible expenses. Revenue generated proceeds are channeled towards investment - capitalization, while profits are expensed off. Researchers (Bierman \& Dukes, 1975; Ball, 1980; Dukes, Dyckman \& Elliot, 1980; Elliott, Richardson, Dyckman \& Dukes, 1984; Kothari, Laguerre \& Leone, 2002) have long analyzed the capitalization versus expensing debate, but it seems that firms tend to use both; extracting benefits from both options. This is an area that requires further research, especially in light of García-Sánchez and García-Meca (2018), emphasizing the pivotal role of managerial skills in investment decision.

\subsection{Corporate Ownership Influences Dividend Policy}

In the US firms prefer more managerial flexibility (Blau \& Fuller, 2008; Franc-Dabrowska, 2009), and exhibit a preference for retaining capital (Tables 4.1, 4.2, \& 4.3); thus, avoiding dividends. However, in other countries dividends are still used. For example, in Austria (Gugler, 2003), while state owned companies paid dividend, family-controlled firms had a significant lower payout ratio. In crisis situations, while family-controlled firms evaded dividends, state-controlled entities were reluctant to change their pro-dividend policy. On the contrary, companies with low growth opportunities hand out dividends, no matter who controlled them.

\subsection{The Case for Dividends}

While it is clear that US firms overwhelming prefer pro-investment policies, at the expense of weeding out dividends, the need arises to analyze the state of affairs in other countries. To the astonishment of many US corporate strategists, companies with strong corporate governance were not only more profitable (Mitton, 2004), but also had higher dividend payout ratios. However, these findings are only possible in countries with strong investor protection. Astrong but negative relationship was established between dividend payout and growth opportunities; the negative correlation is more for firm with better governance. Bena and Hanousek (2008) in a cross-sectional analysis of Czech Republic firms for the period 1996 - 2003, found that in case of bad corporate governance, the majority shareholder would extract rent and expropriate minority shareholder rights, as well as minimize dividends. DeAngelo, DeAngelo and Stultz (2006) findings were also in line with the life-cycle theory of dividends -firms with a high percentage of retained earnings also had high dividend pay-out ratios.

Arnott and Asness (2003) take the low dividend payouts of US firms an indication of strong earnings growth; the study challenges the notion that amassing retained earnings at the expense of dividends does not result in rapid future growth. Regulators should consider the long-term consequences of firms maximizing internally generated funds in the pursuance of the pecking order theory of dividend, as it would lead to capital monopoly, with possible dire consequences for healthy competition.

\subsection{The Fallacy of Dividend Avoidance}

Collings and Kemsley (2000) argue that dividends are instrumental in removing the capital gains tax on reinvested income. In absolute terms, this is really a latent advantage for the investor, as capital gains tax, in addition to corporate taxes seem like a punishment for investors finding the opportunity to invest in profitable corporations. 
Denis and Osobov (2008) found that dividends were characteristic of larger, more profitable firms, whose retained earnings comprised a larger portion of total equity (Mehar, 2005). Financial failures have been the main culprit to cause a decline in dividends. However, in the Japanese corporate landscape, dividend abandonment and failure to initiate (by nonpayers) are economically unimportant. Dewenter, Warther, and Vincent (1998) found that Japanese corporations faced less stock price reactions to dividend commencement and abandonment, because they are less prone to reducing and omitting dividends. Further, their dividend payout is more reflective of the change in earnings. Japanese companies, especially Keiretsu-members, firms face less information asymmetries and less agency problems (which affect dividend policy), as compared to US corporations.

More foreign ownership becomes a major factor in the repurchasing of shares (Liljeblom \& Pasternack, 2006), as a result of dissimilar tax policy for domestic and foreign investors in Finland. Cash distributions were explained in light of the signaling and agency cost theories. In cases where options were dividend protected, the relationship between dividend payout and the scope of the program were significantly positive, although US data report a negative correlation.

Dividend cause stock prices and trading volume (Yilmaz \& Gulay, 2006) to rise a few sessions before cash dividend payments, and on the ex-dividend day. Common stock repurchasing information (Denis, 1981) from the firm also helps boost the company valuation- the ultimate desire of any shareholder.

Gugler and Yurtoglu (2003) found evidence that severe conflict exists between the majority controlling shareholder block and the small outside minority shareholders (Mehar 2005). Empirically the study (Gugler \& Yurtoglu, 2003) documented a 2\% point's reduction for firms where the ownership and control structure made expropriation of minority shareholders more likely. The rent extraction hypothesis has different implications, varying with the levels of dividends paid out. An increase in dividend pay-out ratio increased for the second largest shareholder, while a reduction was noted for the largest group. In accordance to Lintner's (1956) model of dividend determination, the second largest shareholder block with significant equity made a critical difference in the governance of the firm. Further, a negative correlation was established between abandoning the one-share-one vote rule to pyramidal and cross-ownership structures, resulting in larger negative wealth effects and lower dividend pay-out ratios.

Lippert, Nixon, and Pilotte (2000) found that by binding management remuneration to valuation of the firm, the usual positive price response to dividend is supposed to increase due to a couple of reasons. Firstly, by increasing pay-performance sensitivity (PPS) exacerbates management's positive predisposition concerning future company performance, minimizing the integrity of dividend signals. Secondly, by increasing pay-performance sensitivity minimizes the need for dividend as a method of minimizing agency costs. Price sensitivity decreases as pay-performance sensitivity increases, especially in corporations with low market-to-book ratios, in line with behavioral and agency theories. Borokhovich, Brunarshi, Harman and Kehr (2005) also found evidence to support the hypothesis that dividends help reduce the agency problem; however, they reported lack of evidence to support the notion that increasing dividend would further reduce the agency problem.

\subsection{Do Taxes Hinder Dividends?}

Taxation affects the valuation of the firm (Guenther \& Sansing, 2006), both directly and indirectly. Taxes reduce both the variance and mean of after-tax returns -an issue of immediate concern to shareholders. Further, taxes cut into the profitability of the firm, affecting investment decisions, as well as corporate expenses. The implicit valuation (Collins \& Kemsley, 2000) of retained earnings is diminished by capital gains and dividend taxes. They also reduce the dividend and retained earning equity from the investor valuation perspective. Leibrecht, Ballak and Wild (2009) found that a percentage increase in the tax-rate on dividends, resulted in a 3.5\% decrease in repatriation of dividend payment. Alli, Khan and Ramirez (1993) also found support for the tax clientele theory of dividend manipulation, pecking order argument, transaction cost/residual theory, the significant role of dividends 
in mitigating agency problem, as well as a significant role of the management in affecting the company's payout ratio. The research also supported the premise that firms that enjoy financial stability maintain stable dividend policy. Individual dividend tax was reduced (not eliminated) in the tax reform of 2003 (in the US), undermining the justification of insiders (Morck \& Yeung, 2005) to build reservoirs of retained earnings. Halperin (1983) found that in case of high tax law uncertainty, closely held firms tend to increase the salary of owner-managers, while showing an urgency for planning corporate decisions. Most researches have suggested that dividend policy is a factor of the tax regulation. However, Wang, Erickson and Gau (1993) have found that real estate investment trusts (REITs) have higher dividend payout ratios than what is required by taxation regulation.

In support of dividend tax capitalization, the US company-level results of Harris, Hubbard, Glenn and Kemsley (2000) point to the fact that accumulated retained earnings estimated less than paid-in equity. Further, disparity amongst dividend tax rates throughout different states in America, are linked with predictable differences in the degree of the implied tax discount for retain earnings, just as there are varying dividend tax rates in Australia, India, Japan, France, Germany, Pakistan and United Kingdom. In comparison to the American shareholders (Jun et al., 2008), the Australian residents are taxadvantaged, especially in their access to imputation tax credits on Australian stocks. However, Fazzari (1998) argues that tax reformation, despite its success in reducing the cost of capital, will have a very limited effect on the corporate world as well as on economic growth and investment.

In a study of emerging markets Aivazian (et al., 2003) found that firms exhibited similar dividend behavior, when analyzed in light of profitability, debt, and market-to-book ratio. On the contrary, empirical analysis of dividend policy portray different structures; an indication of the differing sensitivities to these variables. Since emerging markets rely more on bank loans, the firm are influenced by the asset mix.

\section{Conclusion}

The early $19^{\text {th }}$ Century devoid of institutional parameters and minimal tax (Braggion \& Moore, 2011), witnessed healthy dividend payouts. Corporate dividend policy is highly influenced (Copeland and Weston, 1992; Alli, Khan \& Ramirez, 1993) by tax legislature (Sterk \& Vandenberg, 1990; Collins \& Kemsley, 2000). Leibrecht, Ballak and Wild (2009) empirically report a 3.5\% loss in repatriation for a single percentage increase in tax. Taxes cut into the profitability of the firm (Collins \& Kemsley, 2000; Guenther \& Sansing, 2006), an issue of concern to shareholders; taxes naturally affect investment issues and dividend policy. However, investors price dividend taxes into stock prices (Harris, Hubbard, Glenn \& Kemsley, 2000), distinguishing between taxable retain earning and tax-free paid-in equity. In fact, dividends (Collins \& Kemsley, 2000) serve as a safer passage for capital to return into the hands of investors, as it eliminates the further possibility of corporate and capital gains taxes, on reinvested profits.

Closely held firms, when faced with uncertain tax legislation (Halperin, 1983), tend to increase management salaries; likewise, there is a sense of urgency when taking decisions. However, REITs are an exception (Wang, Erickson \& Gau, 1993) as they handout out more dividends than required by law.

Table 4.8: Summary of Corporate Tactics \& Governance on Dividend \& Investment

Corporate Governance Influence on Dividend Policy \& Investment Decisions

\section{Dividend}

BOD Compensation

GCG

QCG
Negative, but insignificant

Negative, but insignificant

Negative
Investment

Positive

Positive

Positive 
Corporate governance pursues investment decision, while curbing dividend payout, profoundly by questionable corporate governance.

\section{Corporate Tactics Influence on Dividend Policy \& Investment Decisions}

$\begin{array}{lll} & \text { Dividend } & \text { Investment } \\ \text { Investment } & \text { Negative, but insignificant } & \text { N/A } \\ \text { Market Capitalization } & \text { Negative } & \text { Positive } \\ \text { Pre-Tax Income } & \text { Negative, but insignificant } & \text { Negative } \\ \text { Sales Revenue } & \text { Positive, but insignificant } & \text { Positive }\end{array}$

Sales Revenue (and the firm's value) boost investments, while its positive influence on dividends is insignificant. All other tactics impede Dividend policy, most profoundly by the firm's value. Taxable income impedes investment.

Fama and French (2001) have documented a significant drop (45.7\%) in cash dividend over a twentyyear period (1978-1999), even though investors have a preference (Shefrin \& Statman, 1984) for cash dividends. In line with previous research (Skinner, 2008) and the residual theory of dividend, traditional cash only dividend are now near extinction in the United States. Thus, the effect of corporate governance and tactics on dividend is overwhelmingly negative and insignificant (Table 4.1 - Models 1 \& 2; Figure 4.1; Table 4.6 -Model 6; Model 4.7 - Model 7a \& 7b). Questionable corporate governance casts a profound influence on curbing dividends (Table $4.6 \&$ Model 6). The vibrant corporate governance strategy is not entirely focused on investment capital; firms tend to use the strong positive bidirectional relationship (Table 4.4; Graph 4.2) between sales and investment to ensure growth; in the long run, as per the pecking order theory of dividends, results in retaining and amassing capital. However, profitability tends to limit investment (Table 4.2 - Model 4a; Table 4.3 -Model 4b; Table 4.5 - Model 5a \& 5b; Figure 4.2), possibly in favor of short-term tactics that focus on operating capital, like tax deductible loans, or taxable director/management incentives, which effectively help in lowering the cost of capital. Empirically results suggest that US firms seek to invest funds generated from sales, while expensing off proceeds from profit, benefitting from both capital investment and expensing. Further, repurchasing has become the new trend, seemingly in line with the capital structure substitution theory the capital structure is manipulated in favor of maximizing the earnings per share.

In general (Corina, Mirela \& Mihaela, 2009), shareholders accept the dividend policy of the management, as endorsed by the board of directors, or sell their shares. The residual theory states that dividend should be paid out (Corina, Mirela \& Mihaela, 2009) when a project with positive net present value cannot be found. Pro-dividend and higher pay-out ratios reflective of earnings (Dewenter, Warther, \& Vincent, 1998) help eradicate volatile stock price fluctuation due to anti-dividend policy. Further, a more vocal and active pro-dividend policy (Howe \& Lin, 1992) may also reduce the bid-ask spread. Robust empirical results (Table 4.7 - Model 7a \& 7b) support the argument for higher sales revenue allowing a dividend payout possibility, especially for smaller firms with less valuation and profitability.

The empirical findings (Table 4.5 - Models 5a \& 5b) validate the notion that corporate management (Alli, Khan \& Ramirez, 1993) play their part in shaping the dividend policy, especially the pay-out ratio. Management value flexibility, meaning more operating cash for growth initiatives (Blau \& Fuller, 2008; Franc-Dabrowska, 2009), and less for dividends. While the honest intuition of management may result in long term sustained profitability and growth, it might be at the cost of a dip in the current stock price. Not only is the cost of capital minimized by building mountains of retained earnings (Corina, Mirela \& Mihaela, 2009), but also as a means of keeping out new investors and lenders, and thus limiting outsider 
intervention in the affairs of the governance. Binding managerial remuneration (Lippert, Nixon \& Pilotte, 2000) with stock price, does not help the dividend cause either.

Boyce and Riddle (2008) gives thought provoking alternatives of tax-free and taxable dividends, as viable progressive alternatives of the government carbon cap policy. However, one interesting thing that does come to light is the pro-investor policy of tax-free dividend policy. This is definitely an innovative financial concept that governmental regulatory authorities shy away from, as the government's nutritious budget may initially face deficiency.

In line with the life-cycle theory, firms with more retained earnings with respect to total equity (DeAngelo, DeAngelo \& Stultz, 2006; Denis \& Osobov, 2008) also pursue high dividend payouts policies. In short, financially healthy firms (Alli, Khan \& Ramirez, 1993; Pourheydari, 2009) pursue pro-dividend policy. Small firms, with little paid up capital exhibit the chronic characteristic of dividend avoidance (Mehar, 2005), as they rely heavy on retained earnings for expansion. However, with the exception of Japan, dividend abandonment (Denis \& Osobov, 2008) and failure to initiate (by nonpayers) are economically unimportant. Japanese firms are less prone (Dewenter, Warther \& Vincent, 1998) to dividend omission and minimization, and their dividend pay-out ratio is more reflective of earnings; thus, they experience less volatility in stock prices due to dividend policy.

German firms issue dividends based on cash flow, unlike UK and USA firms (Goergen, Renneboog, \& Correia da Silva, (2004) which are based on actual earnings projected onto long term payout ratios. For German firms, in cases of diminishing profitability, dividends are cut, as opposed to the "smoothness" dividend policy of UK and USA firms. Firms listed on the Euronext Lisbon (Benzinho, 2004) tend to follow relatively smooth cash dividend policy. Poorly performing Hong Kong firms (Cheng et al., 2008) pay cash dividends as per the maturity hypothesis and free cash flow hypothesis; however, they do not support the cash channeling hypothesis.

Austrian state-owned firms tend to be more pro-dividend (Gugler 2003), while family-controlled firms tend to avoid or minimize dividend pay-out. Concentration of ownership (Mehar, 2005) is an important determinant of dividend policy. Debt and dividend both tend to be reduced (Jensen, Solberg \& Zorn, 1992) in cases of high insider ownership. Higher managerial membership (Zhang, 2008) on the board of directors' results in less cash dividends in Mainland Chinese firms, as the agency problem is magnified. On the contrary Chinese and local firms in Hong Kong had a higher dividend payout ratio. Stock prices and trading volume tend to swell (Yilmaz \& Gulay, 2006) as the dividend pay approaches. In case of repurchases, informational signal (Dann, 1981) is the primary factor to boosting valuation. On the other hand, they do significantly influence corporate investment decisions, as postulated by the pecking order, capital structure substitution and residual theories.

The empirical results seem to validate the pecking order, capital structure and residual theories, as well as complimenting empirical finding of research (García-Sánchez \& García-Meca, 2018). Thus, the financial incentives of the board of directors, as well as both good and questionable corporate governance prefer a cash dividend avoidance policy; however, their role in the questionable governance decision making to mitigate dividends is obvious (Table 4.6 - Model 6) and undeniable. Further, investment decisions, the firm value and profitability also obstruct cash dividend policy, as it is evident that US prefer a dividend avoidance policy. In conformance with previous studies, big profitable firms generally avoid cash dividend payout. Dividend policy finds support from sales revenue, while governance (whether good or questionable), firm value, profitability and investment argue for dividend avoidance.

Extending the implied results of (García-Sánchez \& García-Meca, 2018), it would seem that investment decisions are influenced by sales, the financial incentives of directors, good and questionable governance, presumable utilizing the talent and skill of managers in making optimal investment 
decisions. However, profitability and market valuation of the firm tend to hamper investment decisions. It would seem that while firms prefer to capitalize sales, they try to hide away profits as expenses. In a highly ethical world, the governance mechanism to funnel sales revenue into investment, while evaporating profits into expense, would raise eyebrows, especially by taxation regulators, perhaps the least idealist classifying the governance stunt as questionable. Although the empirical results are base on a five-years' time span (2005 - 2009), it does shed light on the capitalization/expensing riddle, while investigating the dividend puzzle.

\section{Research Implications and Recommendations}

The key to reviving the near extinct cash dividend may now have entered the realm of governmental regulators. The concept of double taxes has had a detrimental effect (Guenther \& Sansing, 2006), Leibrecht, Ballak and Wild (2009) on dividends, although few would disagree (Fazzari, 1999). If policy makers do not look into amending double taxes on dividends, the result may be the oblivion of cash dividends, from this current position of near extinction. Dividend avoidance leads to corporate capital monopoly (Gugler \& Yurtoglu, 2003; Morck \& Yeung, 2005).

Weak corporate governance results in large shareholders (Bena \& Hanousek, 2008) extracting rent and expropriating minority shareholders, as well as minimizing dividends. Even the unexpected US federal tax on retained corporate profits of 1936 witnessed (Christie \& Nanda, 1994) a lower growth rate in firms embroiled in the agency problem.

Contrary to the research findings, (Mitton, 2004) suggests strong corporate governance correlates positively with higher dividend payout, and overall profitability in countries with strict investor protection. Improving corporate governance (Bena \& Hanousek, 2008), more particularity the agency problem, will go a long way to improving the firm is several aspects; dividends reduce the agency cost (Borokhovich et al., 2005). Involving the second largest shareholder (Gugler \& Yurtoglu, 2003) in corporate governance may prove to be a crucial strategic option. Lowering managerial membership on the board reduces (Zhang, 2008) the agency problem, and results in improved dividend payout ratio.

Superior innovative corporate governance should cultivate a highly aggressive lean mean negative working capital mechanism, significantly increasing return on capital, as well as freeing up valuable operating capital for growth opportunities as well as dividend payouts. While transformation to a negative working capital may not be easy (Shin \& Soenen, 1998), a realistic goal of near zero working capital may be possible in the near short term. In these regards, management efficiency and effectiveness (Stewart \& Stern, 1991) can be measured by Economic Value Added (EVA) and marketValue Added (MVA). EVA is a good tool to measure managerial effectiveness over a given period, while MVA evaluates the management from the firm's inception.

Regulator bodies should foster polices, regulations and laws to promote dividends; otherwise the strong bidirectional spiraling relationship between sales-investment will continue to result in corporate capital monopolization, while some corporate profits could find their way to (investor) directors and management. This could be achieved by curbing, if not eliminating dividend related taxes. Instigating a tax-free dividend policy (Boyce \& Riddle, 2008) may go a long way to revitalizing dwindling economies. Or more innovatively, redistributing carbon emission revenue to household as taxable dividends, may be a revolutionary technique to benefit the majority of the people, apart from propelling progressive development. Boyce and Riddle (2008) suggestion is one of many interesting possibilities. Why must regimes tax corporation? Why not simply: "earners keeps!" In fact, one could argue that governments are supposed to provide a pro-investment environment. Would a tax-free corporate environment propel unparalleled investment growth? Or should the nation and corporations labor diligently to feed the government and regulatory authorities? The blindly enforced and followed status quo taxation wisdom must be questioned. Surely, countries with superior governance not only survive but also flourish pursuing minimal or tax-free agenda. While Corporate taxes may not be abolished any 
time soon, mitigating dividend tax regime should be investigated. However, Fazzari (1998) argues that tax reformation, despite its success in reducing the cost of capital, will have a very limited effect on the corporate world as well as on economic growth and investment.

Inter-corporate dividend taxes (Morck \& Yeung, 2005) assist in discouraging the formation of pyramidal corporate groupings. Developing countries should study the implementation of the Roosevelt era tax in breaking up corporate groupings. Like the US tax reforms of 2003 (Morck \& Yeung, 2005) and the pre1995 Modarbah (Mehar, 2005) dividend tax exemption in Pakistan, should be pursued by the taxation bodies, minimizing or even eliminating dividend taxes for individuals. In this regard, the Australian dividend imputation may be a step in the right direction. By binding director and management remuneration (Lippert, Nixon \& Pilotte, 2000) to stock price, valuation of the firm will increase, and the dividend policy will be disciplined and balanced between investments and payouts, thus also protecting minority shareholder rights. If the management is really sincere in its proactive evaluation of investment project(s), then there should not be too much left over for dividend (Lippert, Nixon \& Pilotte, 2000); the investor, nevertheless, should be satisfied by the elevated stock price. Further, utilizing managerial expertise (García-Sánchez \& García-Meca, 2018) can help bolster more optimum investment decisions.

Firms should not abandon the one-share-one vote principle (Gugler \& Yurtoglu, 2003) to pyramidal and cross-ownership structures as it correlates with negative valuation of the firm. Granting limited voting rights to common shareholders (Partch, 1987) may be a step in the right direction, without negatively affecting existing shareholders. Further, Australian corporations use a corporate senate (Mehar, 2005) which has the right to amend the recommendations of the board of directors, should be analyzed. The ballots are assessed on a one-shareholder one-vote basis, rather than one-share-one vote basis.

If state owned enterprises can afford to be pro-dividend, then tightly controlled family ventures and corporation should also be whole-heartedly pro-dividend, especially since the Modigliani-Miller argument that dividend policy is irrelevant from the valuation perspective to the investor!

Regulatory authorities, along with global accounting bodies, should review the capitalization/expensing regulation and standards, so as to limit the questionable maneuvering of sales revenue into investment pools, while expensing away profits. Regulator authorities may consider mandating clawback provisions (Lin, 2017), to deter questionable governance practices, especially with regards to investment decisions.

\section{Future Studies}

Future studies should analyses the latent ploy of investing proceeds of revenue and expensing off profits, with macro datasets spanning numerous business cycles; optimizing the revenue/investment and profit/expensing tunnel mechanism seems to set the stage for corporate supremacy, which is an area that requires indebt analysis and investigation.

Researchers should also focus on studying the effect of the Roosevelt era (Morck \& Yeung, 2005) intercorporate tax in other countries, especially developing countries, on discouraging the formation of pyramidal corporate groups. Likewise, the effect of introducing the Bush era tax reforms, which reduced individual dividend tax should also be investigated. Investigating whether non-US investors factor dividend taxation (Harris, Hubbard, Glenn \& Kemsley 2000) into the price, and distinguish between taxable retained earnings and tax-free paid-in equity. Building on the study of Shin and Soenen (1998) MVA and EVA should be used to evaluate the corporate governance and dividend policy of firms in their working capital mechanism deployed. Consistent with previous studies, the results should strengthen the notion that firms with aggressive negative working capital policy have strong corporate governance, and operate in counties with investor protection, in addition to exhibiting good EVA and ROC figures. 


\section{Bibliography}

Aivazian, V., Booth, L. \& Cleary, S. (2003). Do Emerging market Firms Follow Different Dividend Policies From U.S. Firms?, Journal of Financial Research, 26(3):371 - 387.

Akaike, H. (1974), "A new look at the statistical model identification", IEEE Transactions on Automatic Control, 19 (6): 716-723, doi:10.1109/TAC.1974.1100705, MR 0423716.

Akaike, H. (1985), "Prediction and entropy", in Atkinson, A. C.; Fienberg, S. E., A Celebration of Statistics, Springer, pp. 1-24.

Alli, K. L., Khan, A. Q. \& Ramirez, G. (1993). Determinants of Corporate Dividend Policy: A Factorial Analysis, The Financial Review, 28(4):523 -547.

Arnott, R.D. \& Asness, C.S. (2003). "Surprise! Higher Dividends = Higher Earnings Growth", Financial Analysts Journal, January/February 2003.

Ball, R. (1980). Discussion of Accounting for Research and Development Costs: The Impact on Research and Development Expenditures. Journal of Accounting Research, 18, 17-37.

Baltagi, B. E. (1995). Econometric Analysis of Panel Data, John Wiley and Sons, New York.

Bank, S., Cheffins, B. \& Goergen, M. (2009). "Dividends and politics", European Journal of Political Economy, 25(2):224.

Bena, J. \& Hanousek, J. (2008). Rent Extraction by large Shareholders; Evidence Using Dividend Policy in the Czech Republic, Journal of Economics and Finance, 58(3-4):106 - 130.

Benzinho, J. M. (2004). The dividend policy of the Portuguese Corporation: Evidence from Euronext Lisbon, MPRA Paper No. 1137.

Bierman, Jr., H. \& Dukes, R.E. (1975). Accounting for Research and Development Costs. The Journal of Accountancy, January, 48-55.

Boisbunon, A.; Canu, S.; Fourdrinier, D.; Strawderman, W.; Wells, M. T. (2014), "Akaike's Information Criterion, $\mathrm{C}_{\mathrm{p}}$ and estimators of loss for elliptically symmetric distributions", International Statistical Review, 82: 422-439, doi:10.1111/insr.12052.

Bond, S.R. \& Devereux, M.P. (2003). Generalized R-based and S-based taxes under uncertainty, Journal of Public Economics, 87 (5 - 6): 1291 - 1311.

Borokhovich, K. A., Brunarshi, K. R., Harman, Y. \& Kehr, J. B. (2005). “Dividends, Corporate Monitors and Agency Costs" The Financial Review, 40(1):37 -65.

Boumosleh, A. (2009). Director Compensation and the Reliability of Accounting Information, The Financial Review (Eastern Finance Association), 44(4): 525 - 539.

Boyce, J. K., \& Riddle, M. (2008). Keeping the Government Whole: The Impact of a Cap-and-Dividend Policy for Curbing Global Warming on Government Revenue and Expenditure, Political Economy Research Institute, University of Massachusetts, Amherst.

Black, F. (1976). The Dividend Puzzle, The Journal of Portfolio Management, Winter 1976 \& Special issue 1996, pages $8-12$.

Blau, B. M., \& Fuller, K.P. (2008). Flexibility and dividends, Journal of Corporate Finance, 14(2): 133 -152 .

Braggion, F. \& Moore, L. (2011). Dividend policies in and unregulated market: The London Stock Exchange, 1895 - 1905, Review of Financial Studies, hhr026.

Brennan, M. (1970). Taxes, Market Valuation and Corporate Financial Policy, National Tax Journal, 25: $417-427$.

Brooks, R. \& Helms, B. (1990). An N-Stage, Fractional Period, Quarterly Dividend Discount Model, The Financial Review, 25 (4): 651 - 657.

Buda, A. \& Jarynowski, A. (2010). Life-time of correlations and its applications, Wydawnictwo Niezalezne, 1:5-21. 
Chan, S., J. Martin \& J. Kensinger. (1990). Corporate Research and Development Expenditures and Share Value. Journal of Financial Economics, 26:255-276.

Charitou, A. \& Vafeas, N. (1998). The Association Between Operating Cash Flows and Dividend Changes: An Empirical Investigation, Journal of Business Finance \& Accounting, 25 (1 \& 2):225-249.

Cheng, L. T. W., Fung, H.G. \& Leung, T.Y. (2008). What Drives the Cash Dividend Policy of the Poorly performing Firms in Hong Kong, Review of Pacific Basin Financial Markets and Policies, 11(3): 347 - 361.

Christie, W. G. \& Nanda, V. (1994). Free Cash Flow, Shareholder Value, and the Undistributed Profits Tax of 1936 and 1937, The Journal of Finance, 49(5):1727 - 1754.

Cleveland, W. S., \& Devlin, S. J. (1988). Locally weighted regression: an approach to regression analysis by local fitting. Journal of the American Statistical Association, 83(403): 596-610.

Coffee, J. C. (2005). A theory of corporate scandals: Why the US and Europe differ, Oxford Review of Economic Policy, 21(2):198-211.

Collins, J. H., \& Kemsley, D. (2000). Capital gains and dividend taxes in firm valuation: Evidence of triple taxation. The Accounting Review, 75(4), 405-427.

Colpan, A. M. \& Yoshikawa, T. (2012). Performance Sensitivity of Executive Pay: The Role of Foreign Investors and Affiliated Directors in Japan, Corporate Governance: An International Review, 20(6):547:561.

Conyon, M.J. \& He, L. (2012). CEO Compensation and Corporate Governance in China, Corporate Governance: An International Review, 20(6):575-592.

Copeland, T. E. \& Weston, J. F. (1992). “Financial Theory and Corporate Policy”, Addison-Wesley Publishing Company, Massachusetts, USA, p. 544 -608.

Corina, I., Mirela, N. \& Mihaela, G. (2010). Factors that affect dividend policies, Romanian Economic and Business Review, 4(2):83 - 88.

Dann, L. Y. (1981). Common stock repurchases: An analysis of returns to bondholders and stockholders, Journal of Financial Economics, 9(2): 113 - 138.

DeAngelo, H., DeAngelo, L. \& Stulz, R. (2006). Dividend policy and the earned/contributed capital mix: a test of the life-cycle theory, Journal Financial Economics, 81(2): 227 - 254.

Denis, D.J., Hanouna, P. \& Sarin, A. (2006). Is There a Dark Side to Incentive Compensation?, Journal of Corporate Finance, 12(3):467-488.

Denis, David J. \& Osobov, Igor (2008). Why do firms pay dividends? International evidence on the determinants of dividend policy, Journal of Financial Economics, 89 (1):62 - 82.

Dewenter, K. L. \& Warther, V. A. (1998). Dividends, Asymmetric Information, and Agency Conflicts; Evidence from a Comparison of the Dividend Polices of Japanese and U.S. Firms, The Journal of Finance, 53(3): 879 - 904.

Dukes, R. E., T. R. Dyckman \& Elliott, J.A. (1980). Accounting for Research and Development Costs: The Impact on Research and Development Expenditures. Journal of Accounting Research, 18 (Supplement), 1-26.

Elliott, J., G. Richardson,T. R. Dyckman \& Dukes, R.E. (1984). The Impact of SFASNo. 2 on Firm Expenditures on Research and Development: Replications and Extensions. Journal of Accounting Research, 22: 85-102.

Fama, E.F. \& French, K. R. (2001). Disappearing dividends: changing firm characteristics or lower propensity to pay?, Journal of Financial Economics, 60(1): 3- 43.

Fama, E. F. \& Babiak, H. (1968). Dividend Policy: An Empirical Analysis, Journal of the American Statistical Association, 63(324):1132 - 1161. 
Farar, D. \& Selwyn, L. (1967). Taxes, Corporate Financial Policy and Return To Investors, National Tax Journal, 20: $444-454$.

Fazzari, S. M. (1998, January). Capital Income Taxes and Economic Performance. In Proceedings. Annual Conference on Taxation and Minutes of the Annual Meeting of the National Tax Association (pp. 433-437). National Tax Association.

Fazzari, S. M. \& Petersen, B. C. (1993). Working Capital and Fixed Investment: New Evidence on Financing Constraints, RAND Journal of Economics, 24 (3):328-342.

Ferris, S.P., Jayaraman, N. \& Sabherwal, S. (2009). Catering effects in corporate dividend policy: The international evidence, Journal of Banking \& Finance, 33(9):1730 - 1738.

Franc-Dabrowska, J. (2009). Does Dividend Policy Follow the Capital Structure Theory?, Managing Global Transitions, 7 (4): 367 - 382.

Frankfurter, G. M., Wood, B. G. \& Wansley, J. (2003). Dividend Policy Theory and Practice, Academic Press.

García-Sánchez, I. M., \& García-Meca, E. (2018). Do talented managers invest more efficiently? The moderating role of corporate governance mechanisms. Corporate Governance: An International Review, 26(4), 238-254.

Goergen, M., Renneboog, L.D.R. \& Correia da Silva, L. (2004). Dividend policy of German Firms, Center for Economic Research -Discuss Paper (Tilburg University), 2004-122.

Gordon, M. (1962). The Savings Investment and Valuation of a Corporation, The Review of Economics and Statistics, 44(1):37 - 51.

Griffin, J. (1988). A test of the free cash flow hypothesis: Results from the petroleum industry. Review of Economics and Statistics, 70:76-82

Grubert, H. (2009). "MNC Dividends, TAX Holidays and the burden of the repatriation tax: recent evidence", Oxford University Center For Business Taxation, Oxford University, Working paper No. 09/27.

Gugler, K. (2003). Corporate governance, dividend payout policy, and the interrelation between dividends, R\&D, and Capital investment, Journal of Banking \& Finance, 27 (7):1297 - 1321.

Gugler, K. \& Yurtoglu, B. (2003). Corporate governance and dividend payout policy in Germany, European Economic Review, 47(4):731 - 758.

Guenther, D.A. \& Sansing, R. (2006). Fundamentals of Shareholder tax capitalization, Journal of Accounting and Economics, 42(3): 371 - 383.

Gujrati, D. Basic Economitrics $-4^{\text {th }}$ Edition (2004). McGraw-Hill Companies.

Halperin, R. (1983). The perceived instability of tax legislation and its effect on consumptioninvestment, Journal of Accounting and Public Policy, 2(4):239 - 262.

Harris, T.S., Hubbard, Glenn, R. and Kemsley, D. (2000). The Share Price Effects of Dividend Taxes and Tax Imputation Credits, Columbia - Graduate School of Business (Series Papers No. 00-02), p. 44.

Howe, J. S. \& Lin, Ji-Chai (1992). Dividend Policy and the Bid-Ask Spread: An Empirical Analysis, Journal of Financial Research, 15 (1):1 -10.

Jensen. M. (1986). Agency costs of free cash flow, corporate finance, and takeovers. American Economic Review 76:323-29

Jensen, G.R., Solberg, D.P. \& Zorn, T.S. (1992). Simultaneous Determination of Insider Ownership, Debt, and Dividend Policies, Journal of Financial and Quantitative Analysis, 27 (2): 247 - 263.

Jun, A., Alaganar, V. T., Partington, G. \& Stevenson, M. (2008). Price and Volume Behavior around the Ex-dividend Day: Evidence on the Value of Dividends from American Depositary Receipts and their Underlying Australian Stocks-super, International Review of Finance, 8 (1-2):21 - 55. 
Kothari, S.P., Languerre, T.E. \& Leone, A.J. (2002). Capitalizing versus Expensing: Evidence on Uncertainty of Future Earning from Capital Expenditures versus R\&D Outlays, Review of Accounting Studies, 7:355-382.

Leibrecht, M., Ballak, C. \& Wild, M. (2009). Does lowering dividend tax rates increase dividends repatriated? Evidence of intra-firm cross-border dividend repatriation policies by German Multinational Enterprises, Deutsche Bundesbank, Discussion Paper Series 1: Economic Studies, No. 19/2009.

Lintner, J. (1956). Distribution of Incomes of Corporations among Dividends, Retained Earnings and Taxes, American Economic Review, 46(2):97 - 113.

Liljeblom, E. \& Pasternack, D. (2006). Share Repurchases, Dividends and Executive Options: the Effect of Dividend Protection, European Financial Management, 12 (1): 7 - 28.

Lin, Y. C. (2017). Do Voluntary Clawback Adoptions Curb Overinvestment?. Corporate Governance: An International Review, 25(4), 255-270.

Lippert, R. L., Nixon, T. D. \& Pilotte, E. A. (2000). "Incentive Compensation and the Stock Price Response to Dividend Increase Announcements", The Financial Review, 35(4): 69 - 93.

Long, J. B. (1978). The Market Valuation of Cash Dividends: A Case to Consider, Journal of Financial Economics, 6(2): 235 - 264.

Mahar, M. A. K. (2005). Corporate governance and dividend policy, Pakistan Economic and Social review, 1(XLIII): $115-128$.

Meade, J. E. (1978). The Structure and Reform of Direct Taxation, The Institute For Fiscal Studies, London, UK.

Mahboob, F. (2019a). "Business ethics -Hindrance or necessity for corporate profitability: an empirical corporate governance study of US listed firms, forth coming.

Miller, M. \& Scholes, M. (1978). Dividends and Taxes, Journal of Financial Economics, 6(4): 333 364.

Mitton, T. (2004). Corporate governance and dividend policy in emerging markets, Emerging Markets Review, 5(4): 409 - 426.

Modigliani, F. \& Miller, M. (1958). The Cost of Capital, Corporate Finance and the Theory of Investment, American Economic Review, 48(3): 261-297.

Miller, M. H. \& Modigliani, F. (1961). Dividend Policy, Growth and the Valuation of Shares. Journal of Business, 34(4):411-33.

Modigliani, F. \& Miller, M. (1963). Corporate Income Taxes and the Cost of Capital: A Correction, American Economic Review, 53(3): 433 - 443.

Morck, R. \& Yeung, B. (2005). Dividend Taxation and Corporate Governance, Journal of Economic Perspectives, 19(3): $163-180$.

Pang, W. K., Yu, B. W., Troutt, M. D., \& Hou, S. H. (2008). A simulation-based approach to the study of coefficient of variation of dividend yields, European Journal of Operational Research, 189(2): $559-560$.

Partch, M. M. (1987). The creation of a class of limited voting common stock and shareholder wealth, Journal of Financial Economics, 18(2): 313-339.

Poterba, J. (1986). The Market Valuation of Cash Dividends: The Citizens Utilities Case Reconsidered, Journal of Financial Economics, 15(3): 395 - 406.

Pourheydari, O. (2009). A survey of management views on dividend policy in Iranian firms, International Journal of Islamic and Middle Eastern Finance and Management, 2(1): 20 - 31.

Rose, J. (2007). Corporate Directors and Social Responsibility: Ethics versus Shareholder Value, Journal of Business Ethics, 73(3): 319 - 331. 
Sakawa, H., Moriyama, K. and Watanabel, N. (2012). Relationship between Top Executive Compensation Structure and Corporate Governance; Evidence from Japanese Public Disclosed Data, Corporate Governance: An International Review, 20(6): 593-608.

Sethi, S. P. (1996). When Does the Share Price Equal the Present Value of Future Dividends? A Modified Dividend Approach, Economy Theory, 8(2): 307 - 319.

Shaffer, S. (2001). Investor Preference and Dividend Payouts, Applied Economic Letters, 8(7): 489 491.

Sheffrin, H. and Statman, M. (1984). Explaining Investor Preference for Cash Dividends, Journal of Financial Economics, 13(2): 253 - 282.

Shin, H.H. \& Soenen, L. (1998). Efficiency of Working Capital Management and Corporate Profitability, Financial Practice and Education, 8: 37 - 45.

Simons, K. (1994). The Relationship between Dividend Changes and Cash flow: An Empirical Analysis, Journal of Business Finance and Accounting, 21 (4): 577-587.

Skinner, D. J. (2008). The evolving relation between earnings, dividends, and stock repurchases, Journal of Financial Economics, 87(3): 582 - 609.

Sterk, W. E. \& Vandenberg, P. A. (1990). The Market Valuation of Cash Dividends and the Tax Differential Theory of Dividend Policy: A Case Revisited, The Financial Review, 25(3): 441 455.

Stewart, G. B. III \& Stern, J. M. (1991). The Quest For Value” (A Guide for Senior Managers), HarperCollins.

Stock, J.H. \& Watson, M.W. (2008). Heteroskedasticity-Robust Standard Errors for Fixed Effects Panel Data Regression, Econometrica (Journal of the Econometric Society), 76(1):155-174.

Strong, J. S., \& Meyer, J. R. (1990). Sustaining investment, discretionary investment, and valuation: a residual funds study of the paper industry. In Asymmetric information, corporate finance, and investment (pp. 127-148). University of Chicago Press, 1990.

Wang, K., Erickson, J. \& Gau, G.W. (1993). Dividend Policies and Dividend Announcement Effects for Real Estate Investment Trusts, Real Estate Economics, 21(2): 185 - 201.

Weathington, B. L., Cunningham, C.J.L. \& Pittenger, D.J. Understanding Business Research, First Edition, John Wiley \& Sons, Inc. 2012.

Yilmaz, M. K. \& Gulay, G. (2006). Dividend Policies and Price-Volume reactions to Cash Dividends of the Stock market: Evidence from the Istanbul Stock Exchange, Emerging Markets Finance and Trade, 42(4): 19-49.

Zhang, H. (2008). Corporate governance and dividend policy: A comparison of Chinese firms listed in Hong Kong and in the Mainland. China Economic Review, 19(3): 437-459. 